Article

\title{
Navigating Input and Output Legitimacy in Multi-Stakeholder Initiatives: Institutional Stewards at Work
}

\author{
Mikkel Kruuse ${ }^{1, *}$, Kasper Reming Tangbæk ${ }^{1}$, Kristjan Jespersen ${ }^{1} \mathbb{1}$ and Caleb Gallemore ${ }^{2}$ \\ 1 Department of Management, Society and Communication, Copenhagen Business School, 2000 Frederiksberg, \\ Denmark; kasper_tangbaek@hotmail.com (K.R.T.); kj.msc@cbs.dk (K.J.) \\ 2 International Affairs Program, Lafayette College, Easton, PA 18042, USA; gallemoc@lafayette.edu \\ * Correspondence: mk.msc@cbs.dk; Tel.: +45-3815-3208
}

Received: 19 October 2019; Accepted: 21 November 2019; Published: 23 November 2019

\begin{abstract}
Multi-stakeholder initiatives (MSIs) are a form of private governance sometimes used to manage the social and environmental impacts of supply chains. We argue that there is a potential tension between input and output legitimacy in MSIs. Input legitimacy requires facilitating representation from a wide range of organizations with heterogeneous interests. This work, however, faces collective action problems that could lead to limited ambitions, lowering output legitimacy. We find that, under the right conditions a relatively small group of motivated actors, who we call institutional stewards, may be willing to undertake the cost and labor of building and maintaining the MSI. This can help reconcile the tension between input and output legitimacy in a formal sense, though it also results in inequalities in power. We test this claim using a case study of organizations' activities in the Roundtable on Sustainable Palm Oil (RSPO). We find that a small group of founding members-and other members of long tenure-account for a disproportionate level of activity in the organization.
\end{abstract}

Keywords: palm oil; Roundtable on Sustainable Palm Oil (RSPO); institutional work; institutional stewards; multi-stakeholder initiatives (MSIs); legitimacy; sustainability; certification

\section{Introduction}

Global production networks [1,2] and complex supply chains [3], as Abbott and Snidal [4] (p. 2) argue, challenge the "capacity of even highly developed states to regulate activities that extend beyond their borders." These institutional voids allow private sector actors to play governance roles [3,5-8], adopting voluntary programs targeting supply chains' negative social and environmental externalities [4,6,9-11]. Many studies, however, raise fears that private self-regulation could simply be whitewash or greenwash [4,11-13], a mildly reformist extensions of neoliberalism [14]. Whatever their actual effects, these multi-stakeholder initiatives (MSIs), which bring together organizations from public, private, and civil society sectors, have become increasingly common.

Often, studies of MSIs revolve around questions of legitimacy [7] (p. 5), focusing on the formal structure of the MSI as a whole, rather than individual members [15]. Though their membership diversity makes it difficult for single actors to control MSIs, [4], these organizations still are not particularly democratic in practice $[11,13,16]$. International nongovernmental organizations (NGOs) based in the global North, for example, frequently are overrepresented, while smaller organizations from the global South are marginalized [13,17,18].

Other work on MSIs focuses on the organizational strategies and interests driving standards' development $[19,20]$. Several of these document tensions between MSIs' legitimacy as a whole and 
organizational members' heterogeneous interests [15,20]. As Ponte and Cheyns [7] and Green [5] point out, MSIs provide potential benefits for first movers, specific interests, epistemic communities, and powerful actors, whose incentives might differ from overall MSI performance or legitimacy.

While often separate due to their constructivist and rationalist ontologies, the literatures on legitimacy and strategic interests in MSIs both point to an important theoretical question: given inequalities in power, costs, and benefits, why do MSIs often not only persist, but see membership growth? As an initial response, and in contrast to much of the work on MSIs, we focus on micro-level politics [20,21]. Drawing on the literature on institutional work [22], we argue that key stakeholder organizations, who we call institutional stewards, help reconcile the tension between legitimacy and heterogeneous interests in MSIs that endure and grow. Institutional stewards support the institutional maintenance required to keep the organization afloat, in turn enjoying increased influence over the organization's operations. While institutional stewards have outsize influence, raising questions about input legitimacy, they help keep the MSI going in the face of collective action problems and free riding, increasing output legitimacy. To illustrate this claim, we present a longitudinal case study of the Roundtable on Sustainable Palm Oil (RSPO) [7]. Established in 2004 by stakeholders from across the palm oil supply chain, the RSPO presently certifies approximately a fifth of global palm oil production, boasting more than 3400 members [23].

Our work contributes to the literature in several ways. First, the concept of institutional stewards bridges the gap between analyses of bold institutional entrepreneurship and prosaic, workaday institutional maintenance. Even the most stable institutions require actors' ongoing efforts to persist [24,25], but maintenance work is often overlooked [20,26,27]. Second, the difference between institutional creation and maintenance highlights the tradeoff between input and output legitimacy. While institutional stewards enjoy increased influence, they also provide a club good to the remaining members through their willingness to expend resources on maintaining the MSI. Moreover, in the case of the RSPO, as each Ordinary Member is able to vote on proposed changes, even the smaller actors can influence development and potentially break away from the status-quo.

In the following section, we begin by providing an account of the tension between legitimacy and organizational heterogeneity, which can lead to tradeoffs between input and output legitimacy. We then introduce the idea of institutional stewards and consider how member organizations conduct institutional maintenance in MSIs. Next, we outline the methods used to collect data for our case study, including a description of data sources and coding. Before turning to the analysis, we provide a brief overview of the RSPO to establish the context. Finally, we present our analytic findings, followed by a discussion of the contributions and limitations in relation to the functioning of MSIs more broadly.

\section{Balancing Input and Output Legitimacy in Multi-Stakeholder Initiatives}

Increased economic integration in recent decades has fundamentally transformed governance, blurring boundaries between domestic and international jurisdiction [28,29]. Although national governments and international organizations historically played a dominant role as rule-making bodies, they often are unwilling or unable to regulate the negative externalities resulting from cross-border interactions $[3,8,15]$. Some authors suggest that private authority helps fill these governance voids [3,4,8,30-32], and numerous private sector and civil society actors have taken on governance roles [28,33]. MSIs, a common example of private authority $[4,30,34,35]$ and the focus of our analysis here, are created by stakeholder-groups in different supply chains, who draw up rules to induce responsible business behavior $[3,17,36]$.

Legitimacy is a central concern in the literature on private authority in general $[10,28,30]$, as it can be unclear how non-state entities can regulate legitimately. Legitimate institutions benefit from "a generalized perception or assumption that [their] actions [ . . . ] are desirable, proper, or appropriate" [37] (p. 2), and legitimacy helps institutions persist [38]. While actors may accept regulations they do not perceive to be legitimate due to strategic calculations, coercion, or habit [16,39], legitimacy also can lower monitoring and compliance costs. 
MSIs utilize diverse strategies to achieve legitimacy, but these can be simplified into two categories: procedures for taking actions and decisions, or input legitimacy, and benefits from those actions, or output legitimacy [15]. As Mena and Palazzo [15] (p. 14) outline it, input legitimacy is influenced by four factors: "(1) stakeholder inclusion; (2) procedural fairness of deliberations; (3) promotion of a consensual orientation, and (4) transparency of an MSIs' structures and processes." Output legitimacy, on the other hand, is a combination of rules' applicability, efficacy, and enforcement [15]. Additionally, de Bakker et al. [19] identify three main approaches to output legitimacy used by MSIs: certification, principles, and reporting. Certification-based MSIs have mechanisms to verify compliance with a standard established by the members and often utilize third-party verification $[10,19,40]$. Principleand reporting-based MSIs, by contrast, neither offer seals of approval, nor verify compliance, but rather serve as commitments to certain principles [19].

While existing literature justifiably sees input legitimacy as desirable [15,41], ambitious decisions are also more difficult to achieve as organizations' membership increases and diversifies [36]. MSIs' output legitimacy depends on their rigor and robustness, but their ambitions depend on members' ability to reach consensus. Fransen and Kolk [17] (p. 8), for example, suggest MSI initiators are deliberately selective in seeking members during early institutionalization, narrowing the pool for debate to build initial consensus. Given the strength of institutional path dependence [42,43], these early decisions can leave significant legacies for subsequent function and performance $[19,20]$.

Analyses of MSIs often raise questions about input legitimacy [44]. Many studies, for example, note that Northern NGOs tend to be over-represented in MSIs [7,13,15,17,19,45], and governance positions frequently do not include vulnerable groups' representatives [46,47]. There are a range of explanations for this phenomenon. Resource constraints surely block some organizations' participation, particularly in the Global South [15,19,48,49]. Further, as Ponte and Cheyns [7] (p. 12) point out, Northern NGOs often share a common language based on "technical jargon, indirect formulations and a high degree of caution", often prioritizing "global" rather than "local" knowledge [50].

MSIs also face threats to output legitimacy, for which they need efficacious and meaningfully enforced rules [51]. In the case of the RSPO, for example, a critical issue is the degree to which certification actually leads to lower levels of deforestation and fire use than would be expected otherwise, a measure upon which recent studies suggest the organization performs weakly [52,53]. Accordingly, lack of ambition and performance can potentially undermine MSIs' legitimacy in stakeholders' eyes [54].

Input and output legitimacy, however, need not go hand in hand and may at times push against each other. If responses to weak input legitimacy include increasing MSIs' membership heterogeneity, addressing input legitimacy could also make it more difficult to secure robust and coherent commitments, given diverse interests and constraints [55]. While a relatively small number of highly motivated organizations that are interested in using an MSI to create a club good can sustain collective action to keep such organizations going [56], that sort of arrangement is less desirable in terms of input legitimacy.

The push and pull between input and output legitimacy has important implications for the micro-politics of standard-development, where tensions between participation and collective action play out. While there have been numerous calls to investigate MSIs' internal politics, few studies currently exist [19,57-59]. This is likely because the literature that focuses more explicitly on the internal social mechanisms characterizing MSIs often has a different focus. Specifically, DiMaggio's [60] (p. 14) classic work on institutional entrepreneurs, contends that "organized actors with sufficient resources" create new institutions when they "see in them an opportunity to realize interests that they value highly". In this view, institutional change is generally shaped by the interests of powerful or socially skilled actors $[21,61]$. In short, while the literature on legitimacy often sees power relations as a barrier to accepting the institution, power is often a foundation for change in discussions of institutional creation.

Further, as Lawrence \& Suddaby [20] (p. 220) note, even the institutional entrepreneurship literature often fails to analyze what entrepreneurs actually do and how they do it, focusing instead on 
their characteristics and the conditions that produce them. Lawrence and Suddaby's [20] institutional work approach argues that the creation of new institutions requires the support of a wide range of actors [62]. A practice-oriented account [63], institutional work focuses on how actors engage with each other by examining the "purposive action of individuals and organizations aimed at creating, maintaining, and disrupting institutions" [20] (p. 215). Through numerous case studies, the institutional work literature documents how individuals' actions affect institutions on a daily basis, thus bridging the literatures on legitimacy and strategic action $[26,27]$. For our purposes, institutional work is particularly helpful for identifying practices aimed at affecting institutions; the distribution of such activities, in turn, identifies who does what within an MSI.

Whereas institutional work turns attention to mundane actions, it still considers power and the capacity to undertake institutional work [64]. Echoing discussions on MSIs and institutional entrepreneurship, recent studies often find that institutional work is undertaken by elites seeking a central institutional role [65-67]. Often, these actors have in-depth knowledge of the broader institutional field and use their social capital and skills to support their work $[61,68]$.

Though the concepts of institutional work and institutional entrepreneurship have clear similarities, the former is more inclusive because it considers not only institutional creation, but also maintenance and disruption. Battilana et al.'s [69] (p. 68) influential definition of institutional entrepreneurship holds that entrepreneurs initiate divergent changes that "break the institutional status quo in a field of activity" (p. 68). This theoretical construct clearly precludes those who participate in institutional maintenance, despite that this, as well, is strategic work. In response, we coin the term institutional stewards as institutional maintenance's analog to the entrepreneur, defining stewards as actors who initiate non-divergent change, extending fundamental institutional logics into novel circumstances. Similar to institutional entrepreneurs [69] (p. 68), institutional stewards actively participate in implementing change (Table 1), but those changes are reforms intended to preserve the institution as a whole.

Table 1. Institutional entrepreneurs versus institutional stewards $[21,60,69]$.

\begin{tabular}{ll}
\hline \multicolumn{1}{c}{ Concept } & \multicolumn{1}{c}{ Definition } \\
\hline Institutional Entrepreneurs & Actors who leverage resources to initiate and implement divergent change \\
Institutional Stewards & Actors who leverage resources to initiate and implement non-divergent change \\
\hline
\end{tabular}

While conceptually distinct, there are good reasons to expect a strong empirical overlap between institutional entrepreneurs and institutional stewards [20]. Considering the resources institutional maintenance requires, we would expect only actors with a considerable stake in the game to engage in stewardship [56]. Accordingly, the willingness to participate and serve as stewards may depend on institutional resources, although it is difficult to determine a common metric because MSIs span across sectors. For firms, Dang et al. [70] suggest total assets, total sales, and market value of equity as different measurement proxies for size, but these measures do not apply readily to civil society $[48,49]$. In any case, while organizations' size may contribute to institutional work, MSIs can also represent an opportunity to change the status quo for smaller actors [13,42].

As noted above, the institutional entrepreneurship literature presumes actors create institutions because they see this to be in their interest. We also observed that the consolidation of like-minded actors in the initial phases of institutional creation might be a means of making the process more manageable. Taken together, these points suggest that the organizational coalition initiating an MSI is likely to be critical to its maintenance. That is, the constraints of institutional entrepreneurship should select a set of actors or organizations that will later be predisposed to act as stewards. In the case of the RSPO, for example, we would then expect stewards to frequently be organizations that have participated since the MSIs' origins. These initial actors, presumably, determined the initial rules of the game, giving them an early adopter advantage which should increase their stake in the MSI [7]. Considering the effort required to build institutions [26,27], we would expect these actors to preserve their influence on the future development of the RSPO through subsequent maintaining work. In this 
way, the actors who initially served as institutional entrepreneurs are more likely to go on to become institutional stewards.

\section{Methods}

\subsection{Operationalizing Institutional Work}

As there has been relatively limited attention to the internal dynamics of MSIs, we turn to the literature on institutional work, operationalizing organizational activities using the categories identified by Lawrence and Suddaby [20]. We focus on two broad categories of work discussed above: creating new institutions, and maintaining extant ones. More specifically, we focus on the categories of advocacy, defining, and vesting within creation work, and enabling, policing, and deterring within maintenance work.

Advocacy, defining, and vesting together compose the "overtly political work in which actors reconstruct rules, property rights and boundaries that define access to material resources" [20] (p. 221). Specifically, advocacy serves as a means for initially acquiring the legitimacy needed to create institutions through direct representation of specific actors and their interests [20]. According to Suchman [37], advocacy is of particular importance for marginalized actors, since it provides an opportunity to shape the institutional environment through lobbying for additional resources, advertising, and litigation [71]. Next, defining work mainly centers on the creation of constitutive rules, such as membership requirements or standards, which establish the parameters for developing institutional practices [20,72]. Together, advocacy and defining provide the foundation for vesting, mainly pertaining to the allocation of property rights $[20,73]$.

The maintenance work of enabling, policing, and deterring is primarily aimed at "ensuring adherence to rule systems" [20] (p. 230). Because MSIs primarily operate via explicit principles or rules, we focus on maintenance work undertaken to ensure rules remain efficacious. Enabling fosters certainty and agreement in institutional arrangements by introducing rules that facilitate, supplement, and support institutions [20]. Policing is meant to ensure compliance with the rules of an institution through means of enforcement, auditing, and monitoring that may take a "carrot or stick approach" [74] with either sanctions or inducements [20,73]. Finally, deterring seeks to guarantee compliance with the rules by establishing coercive barriers that limit or prohibit institutional change [20].

\subsection{Data Sources}

Our analysis takes a mixed-methods approach, beginning with qualitative coding and content analysis of RSPO documents to outline governance patterns, and to generate datasets that allow us to quantitatively analyze organizational activity within the MSI. This corpus is composed of material available from current and past versions of the RSPO website stored by the Internet Archive. These include key documents about the Membership Rule, RSPO Code of Conduct, Principles \& Criteria, and Statutes [75]. Much of our quantitative analysis relies on data available on the RSPO's membership as of February 2017 [76]. To collect data to analyze membership composition, we utilized the RSPO website's membership search engine to extract the full list of its members. As new organizations frequently join the RSPO, we included the ordinary members from the period 2004 until February 2017 (the cut-off point of data extraction). Due to the absence of archival versions of the RSPO membership list, these data only contain organizations that were members at the time of data collection. As membership departure rates appear to be relatively low, however, we do not believe this significantly affects our conclusions.

We utilized minutes of RSPO General Assembly (GA) [77] and Board of Governors (BoG) [78] meetings from 2004 to 2015 to compile lists of BoG members during that time period, as well as current lists of governing body members to identify membership in those groups. These minutes were also used to identify members that propose resolutions in the GA and to provide context on internal RSPO debates. In addition, we combined attendance summaries posted on several recent RSPO GA websites 
to construct the history of attendance at a sample of recent GAs. Finally, we drew on membership lists presented on the RSPO website [79] to identify members of standing committees, working groups, and task forces as of 2017.

As a means of comparing the RSPO with peer MSIs, we reconstructed the number of prior service years for each organization on the board of the Forest Stewardship Council (FSC), Better Cotton Initiative (BCI), and Roundtable on Responsible Soy (RTRS) since the year 2000. To collect these data, we used a combination of general body meeting minutes and Internet Archive website caches from the respective organizations, all of which are freely available on their websites.

\subsection{Statistical Modelling and Data Visualization}

To test our hypotheses, we estimated regression models predicting the propensity to propose resolutions at the general assembly and serving on an RSPO governing body. Given that resolution proposal is a rare event, we account for zero inflation by estimating zero-inflated negative binomial (ZINB) regression models. An extension of Poisson regression, ZINB models allow for overdispersion in the response variable [80], while the zero-inflated component in the model addresses distributional problems that can arise from observations of zero proposals. [81,82]. The former part, in other words, models the probability of having strictly zero counts, whereas the latter uses a negative binomial regression to model non-zeroes [82] (p. 720). Both excess zeroes and overdispersion are frequent issues in real-life data [83], and accounting for these reduces estimation biases [82]. Since rare events also raise risks of biased coefficient estimates in standard logistic regressions, we used Firth's [84] penalized likelihood estimation approach, as implemented in logistf [85] in R 3.4.1 [86], to estimate logistic regression models to check the robustness of our negative binomial and ZINB estimations.

\section{Background}

\subsection{Origins of the Roundtable on Sustainable Palm Oil}

Global production of palm oil is expected to reach double its 2010 volume and area by 2025 [87]. Palm oil production has historically been geographically concentrated in Indonesia and Malaysia, while consumption is distributed globally (Figures 1 and 2). With growing demand, suitable land in the leading producer countries is becoming scarce [88], and plantings have expanded in Africa and Latin America [89-92], often promoted by national governments [93]. While evidence on direct livelihoods impacts are limited, some recent studies find that smallholder oil palm production improves both village-level assets [94] and household-level livelihoods and nutrition, though the effects are stronger for more affluent households and are driven in large part by farm expansion [95].

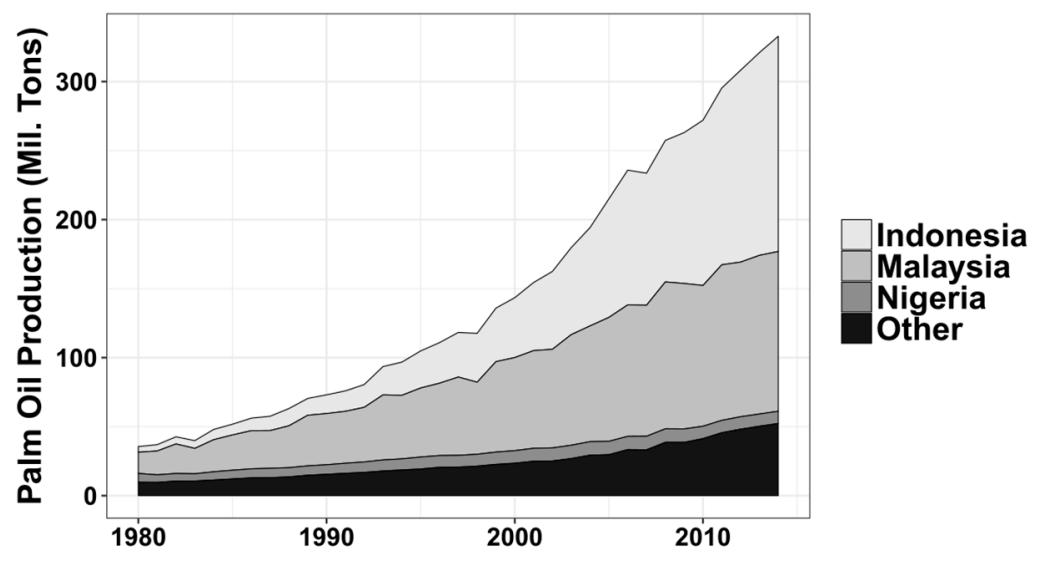

Figure 1. Growth of global palm oil and palm fruit oil production since 1980 [96]. Visualized using ggplot2 [97], in R 3.4.1 [86]. 


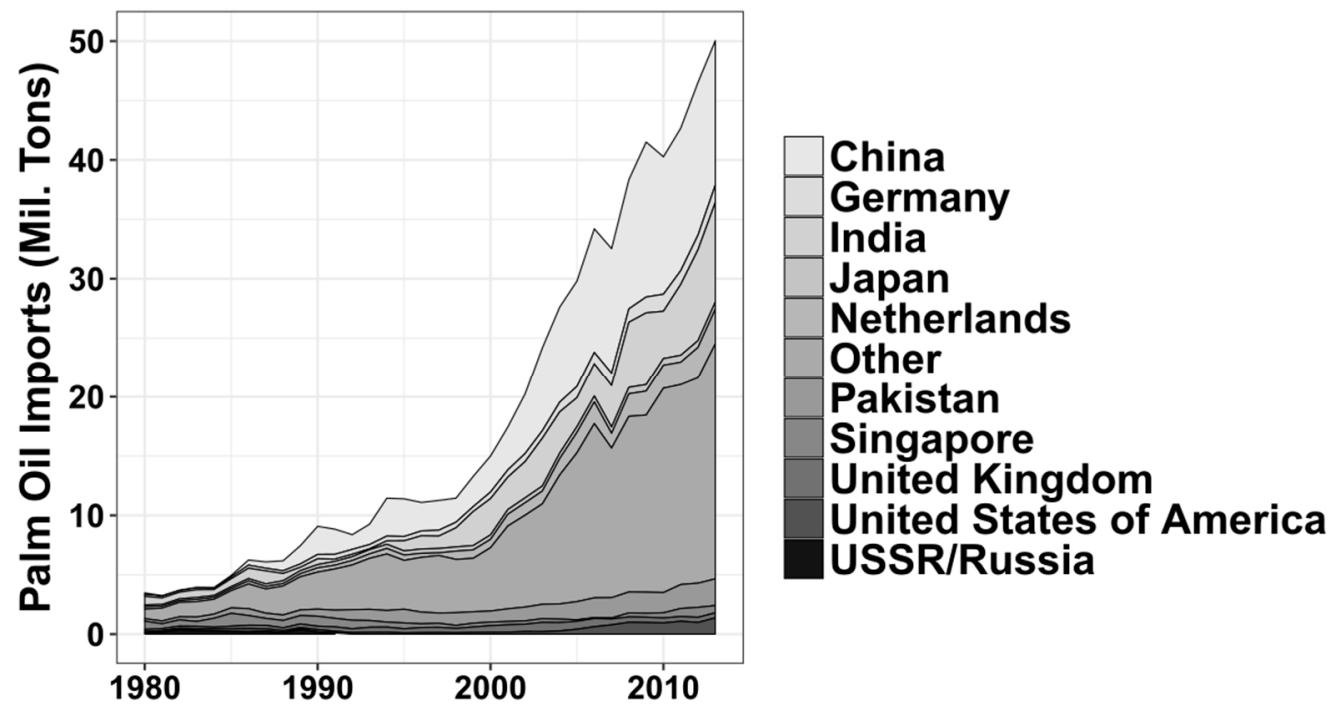

Figure 2. Growth of global palm oil and palm fruit oil imports since 1980 [96]. Visualized using ggplot2 [97], in R 3.4.1 [86].

Economic and production advantages aside, there are serious concerns about palm oil's negative environmental and social impacts. First, natural rainforest, peat swamp forest, and cropland is being converted into oil palm plantations, resulting in biodiversity losses, greenhouse gas emissions, and wildfire [88,98-100]. Second, plantation workers are paid low wages and face precarious, hazardous working conditions. Furthermore, traditional landholders often face expropriation for oil palm production [101-107].

Although the RSPO's founding members include organizations from both the global North and South, it was a group of Northern organizations that started preparations prior to the first GA in 2004 [108]. In 2001, the World Wildlife Foundation (WWF) began engaging stakeholders in the palm oil supply chain, starting with informal collaboration with Aarhus United UK Ltd., Migros, the Malaysian Palm Oil Association, and Unilever [23]. In the same year, responding to increased attention to palm oil's externalities, WWF-Switzerland hired an external consultant to consider a partnership model with businesses to regulate the industry. Having decided on a roundtable format, the next step was to look for potential partners [109]. The process culminated in a meeting in London in September 2002 attended by 16 different European stakeholder organizations, intended to gather support for the proposed initiative and discuss preliminary goals, structure, and working plans [108]. During the meeting, participants agreed that a program driven purely by European interests would potentially be illegitimate [108] (p. 10) and participation of stakeholders from Asia, in particular, would be necessary to secure critical mass and subsequent acceptance by growers [16,108]. These acknowledgements aside, the absence of organizations from the global South at the preparatory meeting in London meant Northern stakeholders drove preliminary defining work for the RSPO: the meeting established the framework for sustainability assessment [108] (p. 9) and the roundtable format [109] intended to "develop and to agree on criteria and standards for sustainable palm oil" [108] (p. 13). WWF's meeting agenda effectively laid the RSPO's foundation, establishing the organization as the RSPO's original institutional steward.

Upon concluding the initial meeting, WWF and Unilever together created an organizing committee for the first roundtable, planned for 2003 [109]. WWF reached out to the Malaysian Palm Oil Association (MPOA) to ensure representation of producing countries [108]. Eventually, the committee included six organizations - the founding members of the RSPO (two of these organizations, Aarhus United UK and Karlshamns $\mathrm{AB}$, later merged to form $\mathrm{AAK}$, which we subsequently identify as a founding member). Each contributed $€ 10,000$ to fund the first roundtable meeting in Kuala Lumpur [110]. Participation in the organizing committee allowed the founding members to have additional influence on defining 
work [20], considering their responsibility for developing the founding rule system [109]. As noted above, these foundational choices can leave important legacies. The RSPO's organizational structure of seven different sectors, for example, was defined before the first GA and has not changed [111]. Similarly, the organizing committee established the BoG's responsibility for resources and programs [109].

\subsection{Development of the RSPO}

As of February 2017, the RSPO boasted over 3400 members divided into four categories: Ordinary, Affiliate, Supply Chain Associate, and Honorary [112]. Members directly participate in RSPO governance through two primary mechanisms: the annual GA meetings, where members propose and vote for resolutions, which direct the RSPO's development; and the Governing Bodies (GBs), including the BoG who oversees implementation and special projects [113]. Only Ordinary Members may propose and vote for resolutions at the GA, and if a resolution is approved, it is further processed by the BoG, a group of sectoral representatives elected by the Ordinary Members and responsible for day-to-day administration [114]. Given their central role in RSPO governance, our analysis focuses on the Ordinary Members.

The RSPO's Ordinary Membership has increased markedly over time, while the overall composition has changed (Figure 3). The RSPO began with 36 Ordinary Members in 2004, a number that has climbed to over 1400. Following a slow initial uptake of new members, growth has increased rapidly since 2010. While some sectors, particularly Banks and Investors and NGOs, have had relatively stable numbers, membership ranks have grown especially for firms operating in the middle of the supply chain, particularly consumer goods manufacturers and processors and traders. The sizeable growth in consumer goods manufacturers, in particular, has shifted the composition of Ordinary Members toward organizations registering their membership in Organisation for Economic Co-operation and Development (OECD) countries. These firms now account for about $70 \%$ of total member numbers (Figure 4). It is possible that the requirements of Ordinary Membership drive some of the differential growth observed in Figures 3 and 4. Oil Palm Growers, for example, are required to submit information on land clearing and other plantation activities upon application [75].

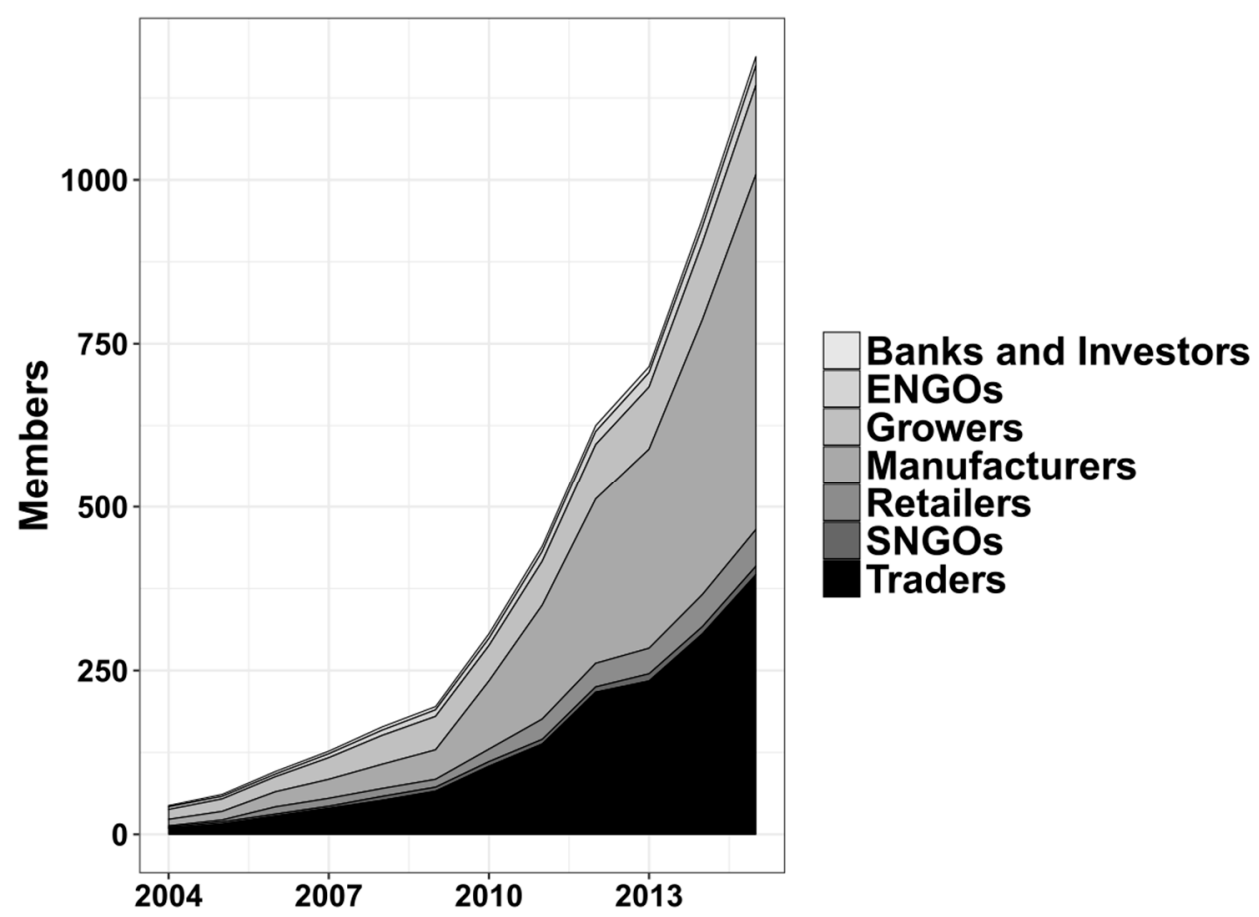

Figure 3. Evolution of Roundtable on Sustainable Palm Oil (RSPO) Ordinary Membership by sector, based on membership roster as of February 2017. Visualized using ggplot2 [97], in R 3.4.1 [86]. 


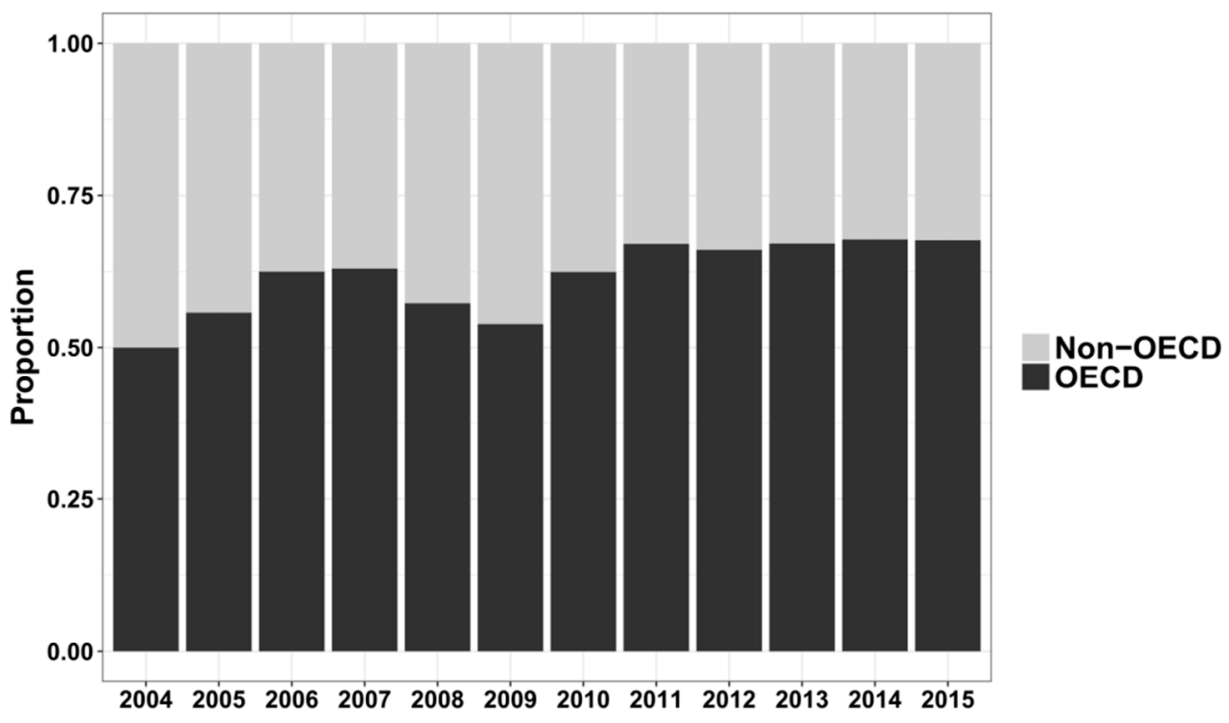

Figure 4. Evolution of RSPO Ordinary Membership by registration in OECD versus non-OECD countries, based on membership roster as of February 2017. Visualized using ggplot2 [97], in R 3.4.1 [86].

\section{Institutional Stewards in the Roundtable on Sustainable Palm Oil}

While the RSPO's membership structure allows heterogeneous groups of members to "express their positions and interests in specific and specialized domains of expertise" [7] (p. 11), past studies have questioned the degree to which power is distributed between and within these sectors [16], with particular attention to the dominance of stakeholders from the private sector and the global North [115]. Our concerns here are slightly different. Given our argument that founding coalitions of institutional entrepreneurs are likely to be willing and able to put in the labor required for institutional maintenance, and, hence, become institutional stewards, we assess the degree to which founding and longstanding members continue to perform the lion's share of key institutional work in the RSPO. As noted above, there are two primary avenues by which Ordinary Members can participate directly in RSPO governance: participation in the GA and service on the BoG and other GBs. In this section, we analyze participation in institutional work in both these arenas.

\subsection{Participation in the General Assembly}

In a formal sense, the GA, which oversees the secretariat and passes resolutions that affect the future direction of the institution, holds fundamental power in the RSPO. Many MSIs, such as the Forest Stewardship Council (FSC), weight voting power to balance different sectors [34]. The RSPO, by contrast, has an unweighted voting system, granting numerically dominant groups, such as consumer goods manufacturers and palm oil processors and traders, significant voting power. Nevertheless, as these sectors have grown, most of the newer members are not bothering to attend GAs (Figure 5). Indeed, the proportion of members attending GAs fell for all sectors between 2012 and 2015.

This general trend, however, hides an important geographic feature of GA attendance. GAs are held in Southeast Asia, so growers, processors, and traders tend to have lower transportation costs, a fact reflected in these sectors' share of recent GA attendees (Figure 6). Specifically, despite that consumer goods manufacturing sector membership numbers have increased significantly over the past several years, their share of total attendees in GAs has declined. Retailers, similarly, have declined as a proportion of actual attendees. While this is offset somewhat by the option of electronic voting, generally only around 25\% of Ordinary Members registered at GAs have exercised this option in recent years. 


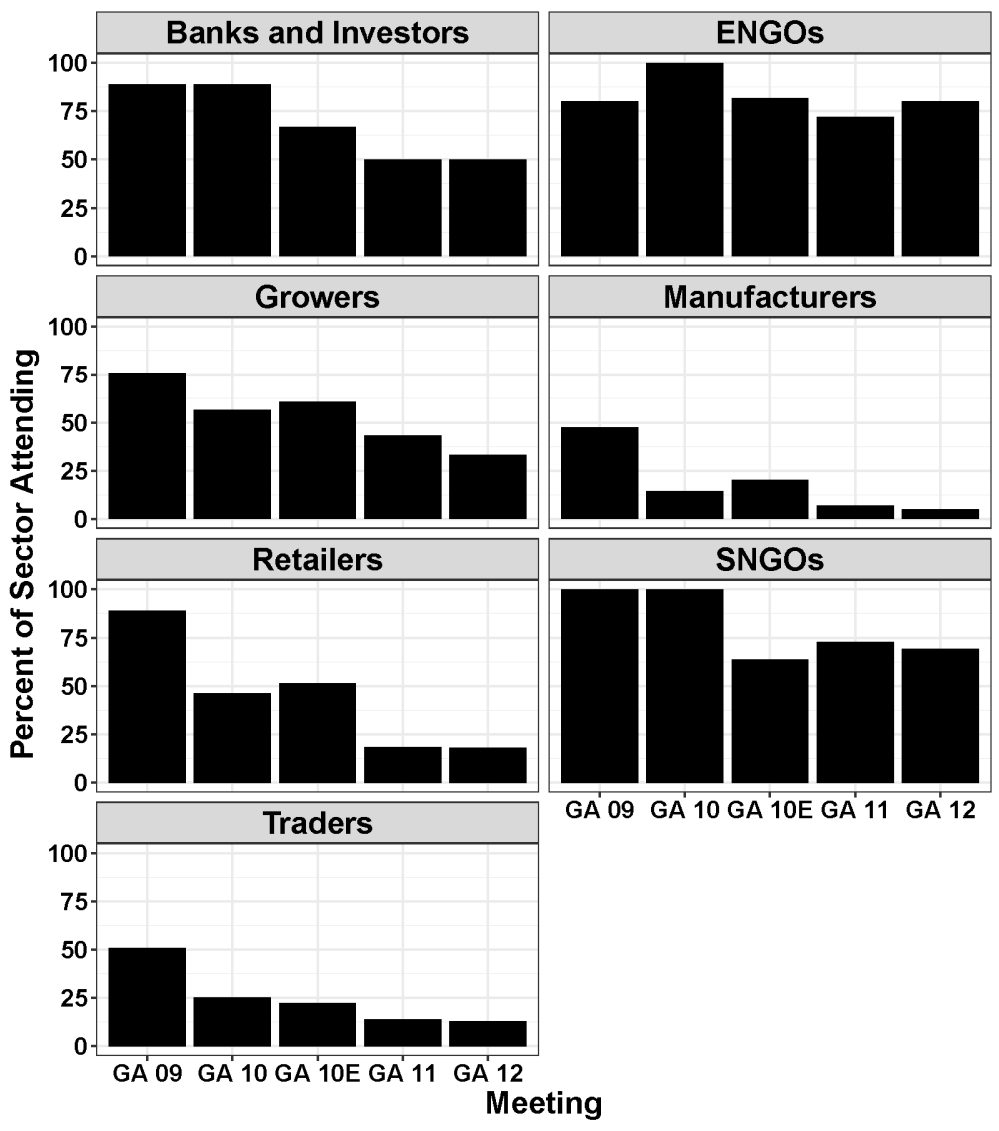

Figure 5. Proportion of Ordinary Members in each sector attending GAs 9 (2012) through 12 (2015). Figure is based on RSPO membership roster as of February 2017. GA 10E refers to an extraordinary General Assembly (GA) held in 2013 to consider addition of greenhouse gas emissions accounting to the RSPO P\&C. Visualized using ggplot2 [97], in R 3.4.1 [86].

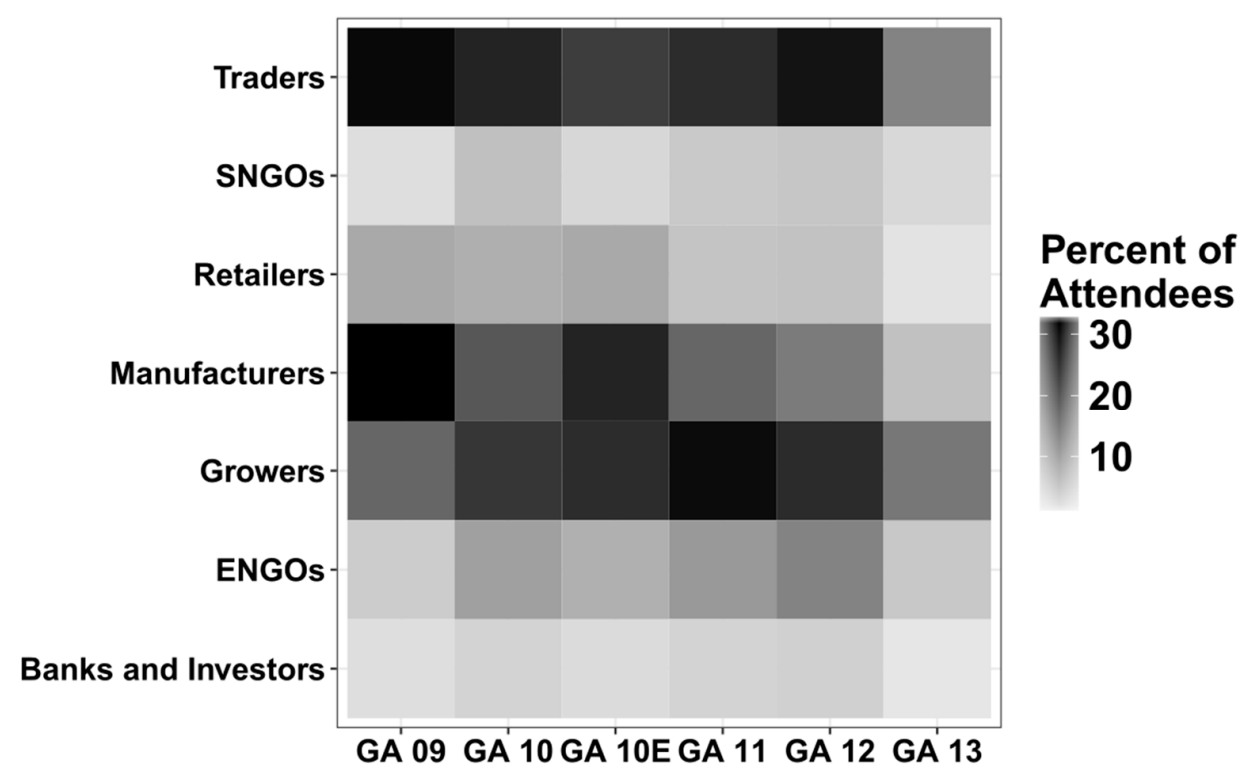

Figure 6. RSPO sectoral attendance at recent GAs, as a percentage of total attendees. Visualized using ggplot2 [97], in R 3.4.1 [86]. 
Of course, members can influence GAs not only by voting but, also, by proposing resolutions to be voted upon. As resolutions set the RSPO's overall direction, they are an important part of institutional work. As a matter of organizational culture, resolutions brought to the GA floor have generally been heavily vetted and, as a result, tend to be likely to pass, making resolution proposal itself an indicator of influence.

If, as we argue, founding members are more likely to act as institutional stewards for the RSPO, we would expect to find that founding members, as well as members with longer tenures, would be more likely to propose resolutions in the GA. To test these claims, Table 2 presents the results of a series of one zero-inflated negative binomial and three logistic regression models predicting the number of resolutions proposed in a given year and the probability that an organization proposes a resolution in a given year, respectively, spanning from the first GA in 2004 until GA 12 in 2015. During this period, only 63 non-procedural resolutions were voted on and, of these, only $55(87 \%)$ had sponsors identified in the minutes.

Table 2. Key variables of interest from estimated models of resolution proposal in the RSPO GA.

Complete Tables in Appendix A.

\begin{tabular}{|c|c|c|c|c|c|c|}
\hline & $\begin{array}{c}\text { Total } \\
\text { Proposed }\end{array}$ & Proposal & Proposal & $\begin{array}{c}\text { Ever } \\
\text { Propose }\end{array}$ & $\begin{array}{c}\text { Ever } \\
\text { Propose }\end{array}$ & $\begin{array}{l}\text { Ever } \\
\text { Propose }\end{array}$ \\
\hline \multicolumn{7}{|l|}{$\begin{array}{l}\text { Negative Binomial } \\
\text { Component }\end{array}$} \\
\hline $\begin{array}{c}\ln (\text { Years of } \\
\text { Membership }+1)\end{array}$ & $\begin{array}{l}-1.30 * * \\
(0.408)\end{array}$ & $\begin{array}{c}0.139 \\
(0.768)\end{array}$ & $\begin{array}{l}2.14^{* * *} \\
(0.523)\end{array}$ & $\begin{array}{l}2.29^{* * *} \\
(0.584)\end{array}$ & $\begin{array}{l}2.70^{* * *} \\
(0.592)\end{array}$ & $\begin{array}{l}2.34^{* * *} \\
(0.596)\end{array}$ \\
\hline BoG Member & $\begin{array}{l}1.00^{* *} \\
(0.330)\end{array}$ & $\begin{array}{c}2.56 \\
(1.21)\end{array}$ & $\begin{array}{l}1.06^{* *} \\
(0.324)\end{array}$ & & & \\
\hline $\begin{array}{l}\ln (\text { Years of BoG } \\
\text { Membership }+1)\end{array}$ & & & & $\begin{array}{l}1.03 * \\
(0.477)\end{array}$ & & $\begin{array}{l}1.52^{* * *} \\
(0.388)\end{array}$ \\
\hline Founding Member & $\begin{array}{c}0.637 \\
(0.391)\end{array}$ & $\begin{array}{l}-1.83 \\
(1.66)\end{array}$ & $\begin{array}{l}3.36^{* * *} \\
(0.468)\end{array}$ & $\begin{array}{c}2.47 \\
(2.00)\end{array}$ & $\begin{array}{l}4.74^{* * *} \\
(1.80)\end{array}$ & \\
\hline \multicolumn{7}{|l|}{$\begin{array}{c}\text { Zero-inflation } \\
\text { Component }\end{array}$} \\
\hline $\begin{array}{c}\ln (\text { Years of } \\
\text { Membership }+1)\end{array}$ & $\begin{array}{l}-5.81 \\
(3.08)\end{array}$ & & & & & \\
\hline BoG Member & $\begin{array}{c}1.21 \\
(1.90)\end{array}$ & & & & & \\
\hline Founding Member & $\begin{array}{l}-5.67^{*} \\
(2.55)\end{array}$ & & & & & \\
\hline McFadden's $\mathrm{R}^{2}$ & 0.560 & & & & & \\
\hline $\begin{array}{c}\text { Area Under the ROC } \\
\text { Curve }\end{array}$ & & $>0.999$ & 0.952 & 0.982 & 0.978 & 0.982 \\
\hline $\begin{array}{c}\text { Coefficient of } \\
\text { Discrimination [116] }\end{array}$ & & 0.229 & 0.092 & 0.106 & 0.0972 & 0.107 \\
\hline $\mathrm{N}$ & 4806 & 4806 & 4806 & 1180 & 1180 & 1180 \\
\hline
\end{tabular}

The final three models are aggregated across the observation period and predict whether or not an organization has ever proposed a resolution. ${ }^{*}=$ sig. at $0.05,{ }^{* *}=$ sig. at $0.01,{ }^{* * *}=$ sig. at 0.001 .

Several significant patterns can be discerned from these models. First, it is clear that founding and BoG members frequently propose resolutions. Based on the zero-inflated negative binomial model, founding members are more likely to propose resolutions, while BoG members are more likely to propose multiple resolutions in a single GA, a finding consistent with the role of BoG in redrafting resolutions. With the exception of NGOs, which in several models appear to be more likely to propose resolutions than other groups, there are no other systematic organizational predictors of proposing resolutions. Importantly, when previous resolution proposal is included in the logistic regression 
models, none of the other variables are statistically significant, pointing to the concentration of proposal activity in a very small share of Ordinary Members across the period studied.

\subsection{Participation in Governing Bodies}

Given the high degree of overlap between founding members, long-term members, and BoG members, it is possible the models in Table 3, while largely as we would expect, partially mask the role of long-term and founding members, attributing some of their activity to service on the BoG. In this section, we examine participation in the BoG and other governing bodies (GBs). Based on our understanding of institutional stewards, we would expect to find that founding and long-term members are also more likely to serve on GBs.

Table 3. Summary statistics of variables used in model estimates in Table 2.

\begin{tabular}{|c|c|c|}
\hline Variable & Time-Series & Aggregated \\
\hline Resolutions Proposed & $\begin{array}{c}\text { Min: } 0 \\
\text { Max: } 8 \\
\text { Mean: } 0.0171 \\
\text { Standard Deviation: } 0.212\end{array}$ & \\
\hline Years of Membership & $\begin{array}{c}\text { Min: } 0 \\
\text { Max: } 11 \\
\text { Mean: } 2.56 \\
\text { Standard Deviation: } 2.54\end{array}$ & $\begin{array}{c}\text { Min: } 0 \\
\text { Max: } 11 \\
\text { Mean: 3.07 } \\
\text { Standard Deviation: } 2.89\end{array}$ \\
\hline $\begin{array}{c}\text { Number of Previous Years } \\
\text { Proposed }\end{array}$ & $\begin{array}{c}\text { Min: } 0 \\
\text { Max: } 3 \\
\text { Mean: 0.0474 } \\
\text { Standard Deviation: } 0.274\end{array}$ & \\
\hline Year & $\begin{array}{c}\text { Min: } 0 \\
\text { Max: } 11 \\
\text { Mean: } 8.44 \\
\text { Standard Deviation: } 2.54\end{array}$ & \\
\hline BoG Membership Years & & $\begin{array}{c}\text { Min: } 0 \\
\text { Max: } 12 \\
\text { Mean: } 0.103 \\
\text { Standard Deviation: } 0.908\end{array}$ \\
\hline BoG Member & 121 & \\
\hline Founding Member & 60 & 5 \\
\hline Registered in OECD & 3156 & 799 \\
\hline Registered in Singapore & 108 & 24 \\
\hline ENGO & 159 & 30 \\
\hline Grower & 726 & 135 \\
\hline Manufacturer & 1883 & 537 \\
\hline Retailer & 282 & 56 \\
\hline SNGO & 80 & 13 \\
\hline Trader & 1594 & 395 \\
\hline
\end{tabular}

\subsubsection{The Board of Governors}

Unlike the GA, where all members can participate and vote, the BoG has a predetermined number of seats that must contain between three and sixteen Ordinary Members [114]. BoG members are elected by the GA for a period of two years, and Ordinary Members may only vote for a representative within their own sector and sub-sector [108]. Generally speaking, the predetermined seats on the BoG help to ensure a more balanced representation of the different stakeholder groups [13], in comparison 
to the GA. Even though some sectors have more representatives than others [114], the BoG—as well as the other GBs-aims for "decision[s] taken in absence of any sustained objection" [113] (p. 27).

Participation in the BoG is particularly important in driving the RSPO's development, and BoG members are inherently able to become institutional stewards. For example, while other Ordinary Members may forward resolutions at the GA, any changes to the standard must be endorsed by the BoG in accordance with the Standard Operating Procedure for Standards Setting and Review [113].

Turnover in the BoG has been quite slow, with elections staggered following a decision taken at GA3, such that there was never more than $25 \%$ turnover in any of the years analyzed. Many member organizations stay on the BoG for multiple terms; around 25\% of GA members have been founding members or members of the original BoG since 2008 (Figure 7). Indeed, all but one of the RSPO's founding members have remained on the board consistently. In the remaining seats, organizations frequently serve consecutive terms as BoG members. GA minutes from 2004-2015 [77] reveal the vast majority of elections were uncontested, and the seat reserved for smallholders remained vacant for the RSPO's first two years before being allocated. This pattern can be seen in Figure 8, which presents the distribution of years of service on the BoG for organizations with at least one year of service. The distribution has a long tail, with peaks at around two and ten years of service, indicative of a small group of very long-serving members.

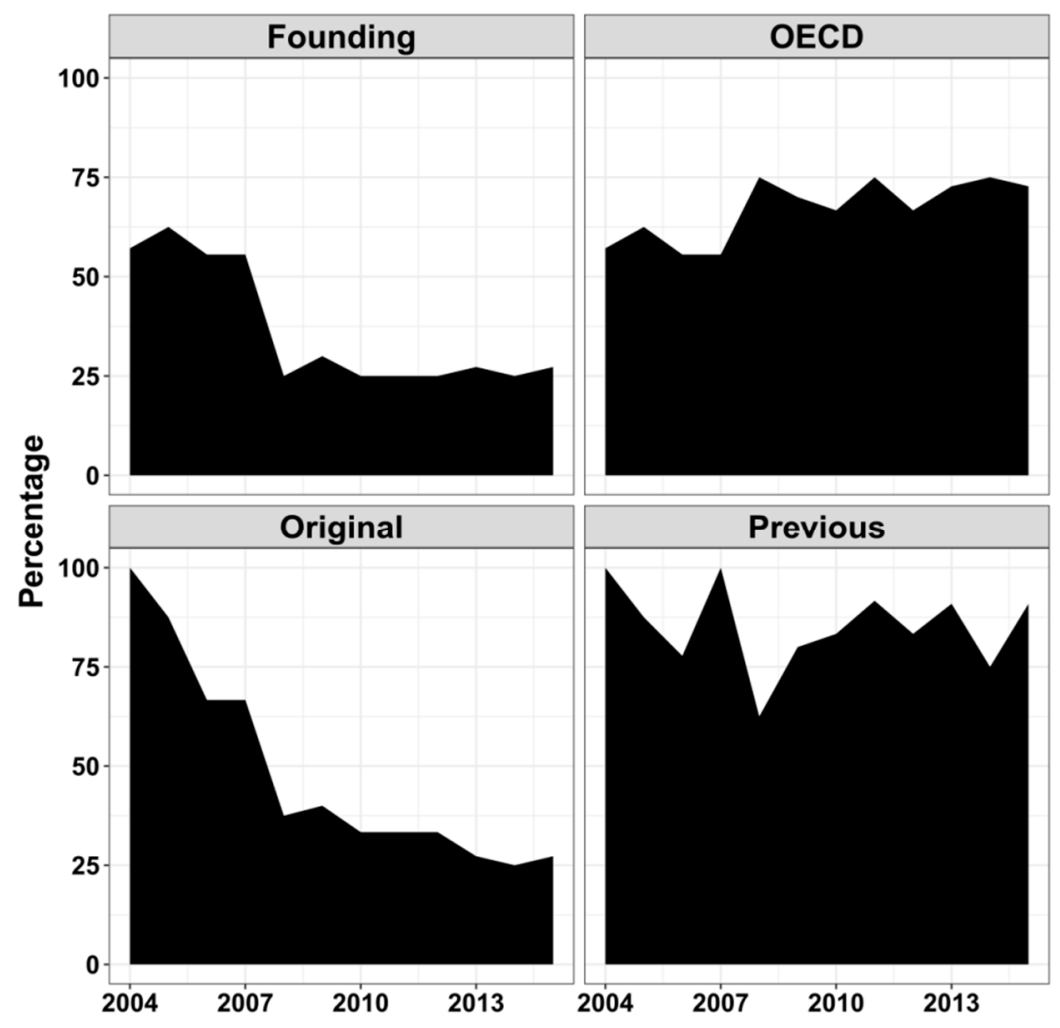

Figure 7. Share of founding, original Board of Governors (BoG), OECD, and previous year BoG members on the BoG, over time. Visualized using ggplot2 [97], in R 3.4.1 [86].

In contrast to patterns of GA attendance, the distribution of sectoral representation in the BoG tilts toward OECD countries, whose share of BoG members has been slowly climbing since the RSPO was founded (Figure 7). Throughout the study period, Northern organizations have occupied approximately two thirds (62.3\%) of BoG seats, in comparison to a little over one third (37.7\%) for the South. NGOs initially followed a trend of equal distribution between North and South, but since 2009 for Environmental or Nature Conservation Organizations, and 2013 for Social or Development Organizations, Northern members have occupied both seats. The composition of BoG seats held by the 
remaining sectors has remained fairly consistent with their sectoral composition: the two seats for Palm Oil Processor and/or Traders have been evenly divided between North and South members, whereas consumer goods manufacturers, retailers, and banks and investors have all been from the North.

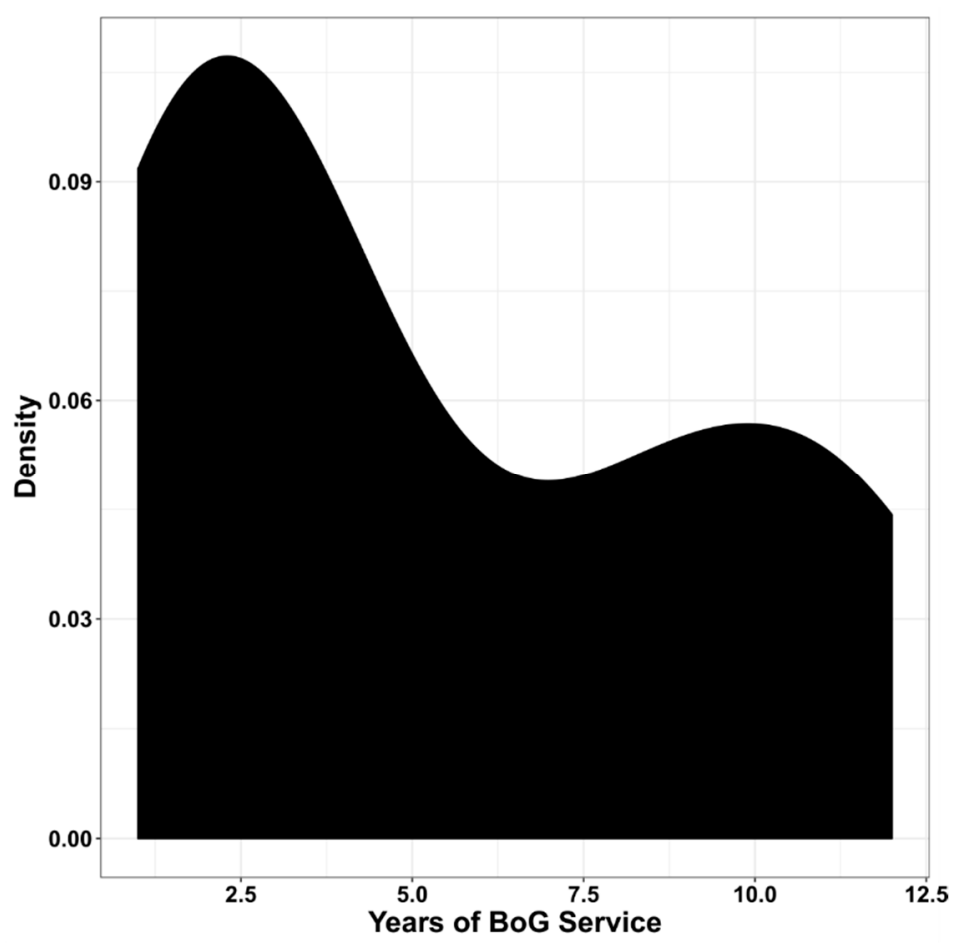

Figure 8. Distribution of years of BoG membership for current RSPO Ordinary Members with at least one year of service on the BoG. Visualized using ggplot2 [97], in R 3.4.1 [86].

\subsubsection{Other Governing Bodies}

Whereas BoG members are elected by Ordinary Members at the GA, the remaining GBs are appointed [15,40]. Officially, the Standing Committees (SCs) are composed of "members from the $\mathrm{BoG}$, or their respective alternates, and RSPO members and strives for balanced representation of all membership categories" [113] (p. 6). Nevertheless, it is at the sole discretion of the BoG to determine what counts as balanced representation [113]. Subsequently, the SCs are responsible for deciding whether it is necessary to establish a Working Group (WG) or Task Force (TF) to undertake more detailed work [113]. Whereas the annual GA has been hosted in Southeast Asia since the founding of the RSPO, GB meetings take place throughout the world. From the available minutes, the majority of WG and TF meetings appear to take place in an Asia, while the locations of BoG and SC meetings are more evenly divided between Europe and Asia [75]. Figure 9 depicts the membership overlap among the GBs (including the BoG) for which membership rosters were available as of February 2017. Founding members are labelled, while BoG members are displayed in black. The visualization utilizes Fruchterman and Reingold's [117] algorithm to place GBs and organizations, which locates organizations serving on GBs with overlapping membership more closely together. Both GBs and organizations are sized by their network degree, which for organizations is the number of GBs on which they serve and, for the GBs, is the number of organizations with a seat. The visualization suggests a relatively small group of organizations serve on several GBs, forming a core with the potential to connect discussions taking place on different issues. Two of these organizations are founding members, while a third founding member, AAK, serves on two GBs in addition to the BoG (We have excluded the Finance Committee from the visualization, as the membership is not listed on the RSPO site. However, AAK has an ex officio seat on the Committee by virtue of its role as Treasurer on the BoG). 


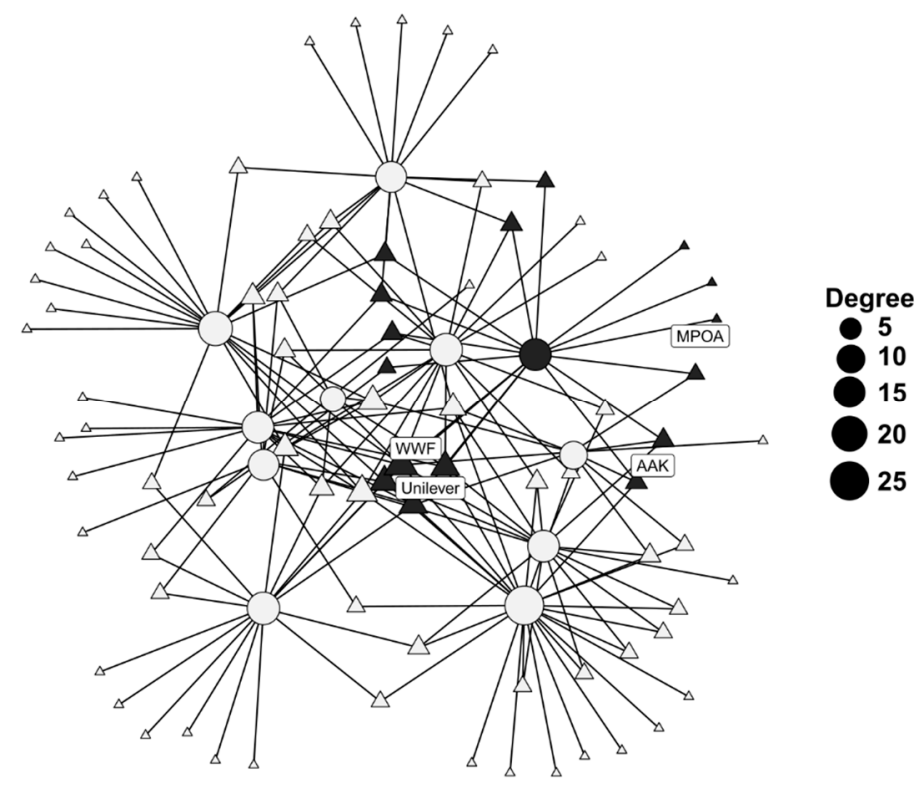

Figure 9. Network of currently active Governing Bodies (GB) membership. Nodes sized by degree (the number of connections they have to other nodes). Visualized using ggplot2 [97], in R 3.4.1 [86]. GBs displayed as circles; GB members displayed as triangles. BoG members and BoG displayed in black.

Given the relatively small number of GBs, organizations' centrality in Figure 9 is driven in large part simply by the number of GBs upon which an organization serves. Again, in keeping with our assumptions about institutional stewards, we would expect founding members and members of long tenure to be more likely to serve on GBs than other organizations. Table 4 tests this claim, using models that predict either the number of GBs (other than the BoG) on which an Ordinary Member is currently serving, or the probability that an Ordinary Member serves on at least one GB. We estimate zero-inflated Poisson and negative binomial models, as well as Firth's [84] penalized likelihood logistic regression estimation [85] for the same reasons as described above in the case of resolution proposal. Summary statistics for the variables used are presented in Table 5.

Table 4 demonstrates that while, as expected, members of longer tenure are more likely to be members of GBs other than the BoG, founding members are not more likely than others to serve on a GB, controlling for BoG membership, which, as expected, has a statistically significant, positive relationship with further GB membership. Interestingly, we do not find an improvement in model fit when moving from a zero-inflated Poisson to a zero-inflated negative binomial regression model, suggesting that, controlling for the variables in the model, there is no additional overdispersion. In other words, the propensity of organizations that serve on multiple GBs to serve on quite large numbers of GBs is effectively accounted for by the variables in the model. 
Table 4. Key variables of interest from estimated models predicting current GB membership.

\begin{tabular}{|c|c|c|c|}
\hline & $\begin{array}{l}\text { Number of GBs } \\
\text { (Poisson) }\end{array}$ & $\begin{array}{c}\text { Number of GBs } \\
\text { (Negative Binomial) }\end{array}$ & On One GB \\
\hline \multicolumn{4}{|l|}{$\begin{array}{c}\text { Poisson/Negative Binomial } \\
\text { Component }\end{array}$} \\
\hline $\ln ($ Years of Membership +1$)$ & $\begin{array}{l}0.883 * \\
(0.427)\end{array}$ & $\begin{array}{c}0.791 \\
(0.485)\end{array}$ & $\begin{array}{l}1.42^{* * *} \\
(0.313)\end{array}$ \\
\hline BoG Member & $\begin{array}{c}0.431 \\
(0.336)\end{array}$ & $\begin{array}{c}0.526 \\
(0.467)\end{array}$ & $\begin{array}{l}4.42^{* * *} \\
(1.22)\end{array}$ \\
\hline Founding Member & $\begin{array}{c}-0.420 \\
(2.60)\end{array}$ & $\begin{array}{l}-0.709 \\
(0.851)\end{array}$ & $\begin{array}{l}-1.62 \\
(1.42)\end{array}$ \\
\hline \multicolumn{4}{|l|}{ Zero-inflation Component } \\
\hline $\ln ($ Years of Membership +1$)$ & $\begin{array}{l}-1.31^{* *} \\
(0.459)\end{array}$ & $\begin{array}{l}-1.40 * \\
(0.633)\end{array}$ & \\
\hline BoG Member & $\begin{array}{l}-5.13 * \\
(2.32)\end{array}$ & $\begin{array}{l}-5.31^{* *} \\
(1.84)\end{array}$ & \\
\hline Founding Member & $\begin{array}{l}1.63 \\
(6.49)\end{array}$ & $\begin{array}{l}0.847 \\
(2.76)\end{array}$ & \\
\hline McFadden's $\mathrm{R}^{2}$ & 0.370 & 0.360 & \\
\hline Area under the ROC Curve & & & 0.933 \\
\hline $\begin{array}{c}\text { Coefficient of Discrimination } \\
\text { [116] }\end{array}$ & & & 0.08 \\
\hline $\mathrm{N}$ & 1123 & 1123 & 1123 \\
\hline
\end{tabular}

Based on a likelihood ratio test $\left(\chi^{2}=1.39, p=0.239\right)$, we find no statistically significant improvement in model fit from the Poisson to the negative binomial models. ${ }^{*}=$ sig. at $0.05,{ }^{* *}=$ sig. at $0.01,{ }^{* * *}=$ sig. at 0.001 .

Table 5. Summary statistics for variables used in Table 4.

\begin{tabular}{cc}
\hline Variable & Summary \\
& Min: 0 \\
Total Seats on Governing Bodies & Max: 11 \\
& Mean: 0.103 \\
& Standard Deviation: 0.637 \\
Years of Membership & Max: 11 \\
& Mean: 3.11 \\
BoG Member & Standard Deviation: 2.92 \\
Founding Member & 5 \\
Headquartered in OECD & 750 \\
Headquartered in Singapore & 24 \\
ENGO & 30 \\
Grower & 133 \\
Manufacturer & 495 \\
Retailer & 55 \\
SNGO & 13 \\
Trader & 383 \\
\hline
\end{tabular}

\section{Discussion}

Across a range of indicators, our findings support the claim that the RSPO is largely administered by a relatively small group of members, generally of long standing. Beginning with the observation that input legitimacy is insufficient to understand the role of private authority in economic governance [7], it is important to consider a range of daily institutional work in order to better understand power 
and participation within MSIs [115] (p. 419). While institutional work is often understood as a typology of activities based on empirical cases [118], here we have used the literature as a theoretical framework, directing our attention to the distribution of everyday activities to understand which organizations are running the show. As our analysis indicates, the distribution of everyday institutional work may create power relations quite different from those that might be expected from formal institutional arrangements.

Early RSPO members remain critical for the institution's continued operations. Six organizations, all of whom were either founding members or served on the first official BoG, for example, sponsored or co-sponsored 60 percent of the resolutions approved during the GAs covered by our dataset. Resolution proposal, however, is not the only way in which entrepreneurs continue to influence the RSPO. They act as institutional stewards in making outsize contributions to workaday concerns through service on the BoG and other GBs. Involved both in creating and maintaining institutions, these organizations have remained central to the RSPO throughout its history.

We believe this path-dependent source of cleavage may be as important as the more commonly remarked North/South divide in MSI politics [11,17,45]. In terms of formal membership composition, to be sure, the RSPO appears consistent with literature that suggests MSIs are driven by actors originating from the global North $[13,15,19,30]$. Nevertheless, some of the most central actors are from the global South, and in practice participation is more complex. In specific, the GBs generally seem to be comprised of larger organizations, regardless of their country of origin. It is noteworthy that, while we find Ordinary Members headquartered in the OECD are more likely to serve on GBs, this relationship is even stronger for members headquartered in Singapore, suggesting a combination of affluence and geographic location may be at play. In addition, we find that, controlling for BoG membership and membership tenure, organizations from the OECD are no more likely to propose resolutions in the GA than other members. Further, the profile of members' attendance at recent GAs suggests direct participation in governance may be more equitably distributed across sectors in practice than formal membership rolls might suggest.

These observations return us to the question of legitimacy. While the MSI literature often points to inequitable North/South representation as a challenge to input legitimacy $[7,15,17,19]$, our analysis indicates challenges to legitimacy may be more complex. On the one hand, limited participation in the GAs, as well as the questions of sectoral and geographic representation raised above, could be risks to input legitimacy, but, on the other, institutional stewards' investments in the institution may be necessary for performance and, as a result, output legitimacy.

On this interpretation, the presence of a strong core of institutional stewards might shield the RSPO—and similar MSIs—-from the collective action problems $[55,56]$ that might otherwise lead to the institutional collapse. One suggestive point that speaks to this claim is the fact that so many BoG elections are uncontested (indeed, the smallholder seat remained open for the first two years of the RSPO's existence). While it is possible this is because BoG members' positions are so secure as to render them unassailable, the lackluster attendance and low level of activity at the GAs (there are only 61 distinct resolution sponsors in our dataset), tends to suggest foot-dragging, rather than fear, better explains the lack of competition.

A final consideration here is whether or not this pattern is characteristic of most MSIs. Some support for this proposition is found in Figure 10, which presents the distribution of years of tenure for a selection of top MSI governing boards, based on publicly available records. While this is only a tentative indication, it seems clear that the centrality of institutional stewards noted in the RSPO is found in some, but not all, of the top governance bodies in comparable MSIs. The well-established (and term-limited) Forest Stewardship Council (FSC), for example, exhibits relatively stable median membership tenure in their top governance bodies. Longer, non-consecutive, terms of service are possible but very rarely achieved. The more recently established Better Cotton Initiative (BCI), Roundtable on Responsible Soy (RTRS) and the RSPO itself exhibit a pattern of lengthening median tenure, each exhibiting a small number of outlier board members that are reelected continuously. While these patterns are of 
course affected by the diverse electoral and term rules of the MSIs represented, this straw-in-the-wind test suggests comparative analysis of the distribution of institutional work within a range of MSIs could be a promising avenue for further research on the conditions favorable to the emergence of institutional stewards.

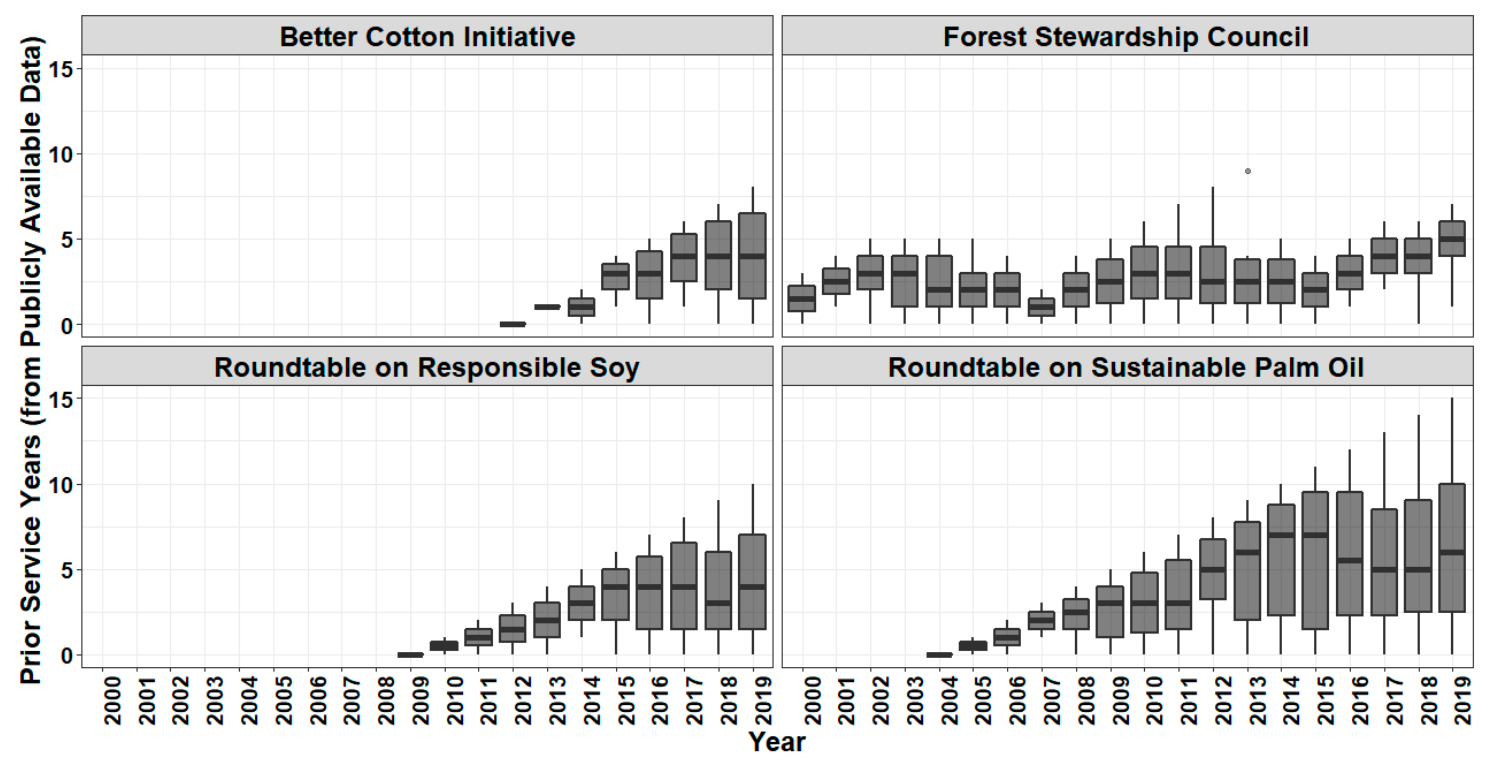

Figure 10. Boxplots of number of previous years of service on top governing bodies, by organization, for a selection of multi-stakeholder initiatives (MSIs) from 2000 to 2019. Note that, because of reliance on publicly available data, figures for the Better Cotton Initiative (BCI) and Marine Stewardship Council (MSC) likely underestimate the service tenure of governing body members for the first few years of the dataset. Because the BCI allows multiple governing body members from the same organization, the BCI figures represent count each individual's service as one year of service for the organization by which they are employed. Governing bodies considered: BCI Council, BCI; Board of Directors, FSC; Board of Trustees, MSC; Executive Board, RTRS; and Board of Governors, RSPO. Visualized using ggplot2 [97], in R 3.4.1 [86].

The above analysis offers the following key contributions to the literature. First, through a longitudinal study of the RSPO, we shed light on the different phases of institutional development. Whereas the work aimed at creating institutions is well understood, institutional maintenance has gained relatively little attention despite its importance [20]. Scholars tend to focus on successful implementation of institutional change [119], often in a single type of organization [120]. Second, we introduce the concept of institutional stewards to characterize the different roles that actors assume throughout the lifecycle of an institution. We find that the RSPO has largely been governed by a few organizations that started out as the initial entrepreneurs who went on to become its stewards.

Although limited participation of organizations in the development process may raise concerns over legitimacy, our findings suggest we must consider input and output legitimacy in tandem to gain a comprehensive understanding of the role of private authority in economic governance [7]. While there is a strong overlap between entrepreneurs and stewards, BoG elections are usually uncontested. The lack of competition is thus unlikely to be due to inherently low input legitimacy. Moreover, the predetermined seats for each sector help promoting a balanced stakeholder representation, although it should be noted that these are often occupied by large organizations within the sectors, further highlighting necessity of access to resources. Still, the ability of every Ordinary Member to propose and vote on resolutions enables smaller organization to assert a degree of influence over institutional development, as well. Finally, whereas organizations may gain greater influence by expending resources, their willingness to do so is central in maintaining institutions in the face of collective action problems. 
Naturally, our study entails certain limitations. The reliance on public records means restricted access to data may have implications for our validity. In terms of BoG participation, for example, it was possible to establish an accurate overview of how the composition has developed over time, and as such we are fairly confident in the results. Conversely, we could only obtain complete information on a limited number of GBs. We initially considered including previous GBs in our sample, but decided to focus on those currently active, as those were the ones for which the most complete data were available [121]. Additionally, 13 resolutions outlined in the GA minutes did not indicate a clear sponsor.

Overall, it is important to note that our results pertain to a single case study. Future studies should undertake comparative analysis of other MSIs or similar arrangements to test the robustness of our conclusions here. The discussion section provides some tentative evidence for a few select initiatives, but further research clearly is required to further test these first impressions. A final consideration relates to organizations' willingness to participate in institutional development. Whereas we identify a range of defining characteristics for the actors that are more likely to become institutional stewards, our study cannot explain in detail why they are willing to do so. Throughout this study, we assumed new institutions are created when organizations with sufficient resources find an opportunity to further their interests [60] (p. 14). Maintenance work is thus simply perceived as a means to secure the persistence of organizational interests. More nuanced exploration of the motivations for participating in institutional work, however, remains a key question for future research.

\section{Conclusions}

Our case study of the distribution of institutional work in the RSPO suggests the organization's development has been driven in large part by relatively few organizations that undertake the lion's share of institutional work intended to create new and maintain extant institutions. While this dominance raises questions about input legitimacy, critical to institutional survival $[15,20]$, it is unclear the degree to which this dominance is driven by exclusion or by apathy. To the extent that institutional stewards run the show in the RSPO, they may help balance the tension between input and output legitimacy in the face of collective action problems.

Whereas our analysis allows us to identify institutional stewards, it does not explain why these organizations take up these roles. While there is certainly an incentive for first movers to put in the labor to build institutions that will subsequently govern them as a means of expanding influence [13], future research would do well to identify the conditions under which institutional entrepreneurs have the motivation, and the endurance, to stay on as institutional stewards. In addition, it would be helpful to undertake comparative analysis of multiple MSIs to better understand the situations in which institutional stewards can contribute positively to organizations' functioning.

Author Contributions: Conceptualization, M.K., K.R.T., K.J. and C.G.; Data curation, M.K. and K.R.T.; Investigation, M.K., K.R.T. and K.J.; Methodology, M.K., K.J. and C.G.; Visualization, K.R.T. and C.G.; Writing — original draft, M.K., K.R.T. and C.G.; Writing—review \& editing, M.K., K.J. and C.G.

Funding: This research received no external funding.

Acknowledgments: We thank the master's students in the Impact for Innovation Lab at Copenhagen Business School for helpful feedback and support.

Conflicts of Interest: The authors declare no conflict of interest. 


\section{Appendix A Complete Model Tables}

Table A1. Estimated models of resolution proposal in the RSPO GA.

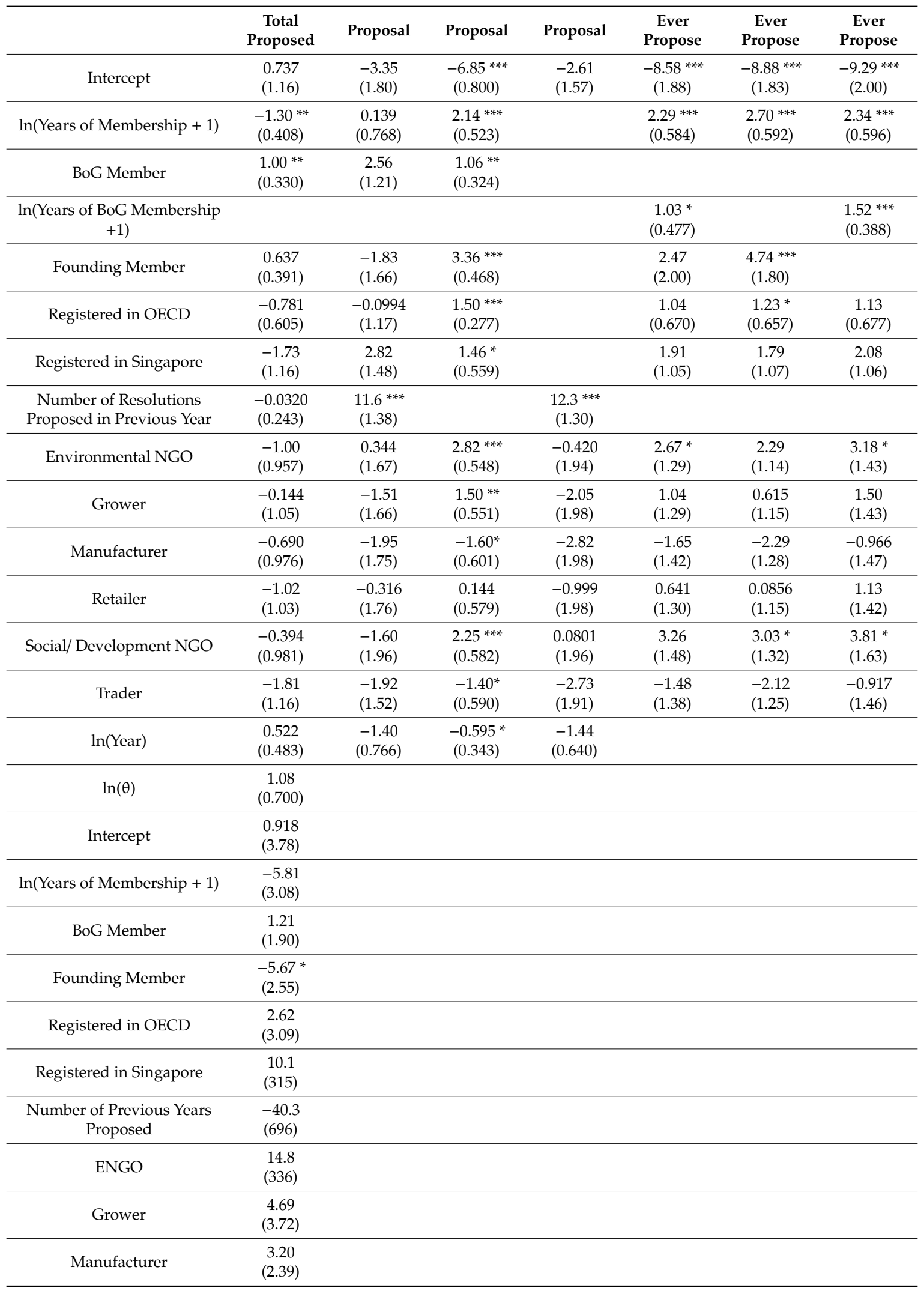


Table A1. Cont.

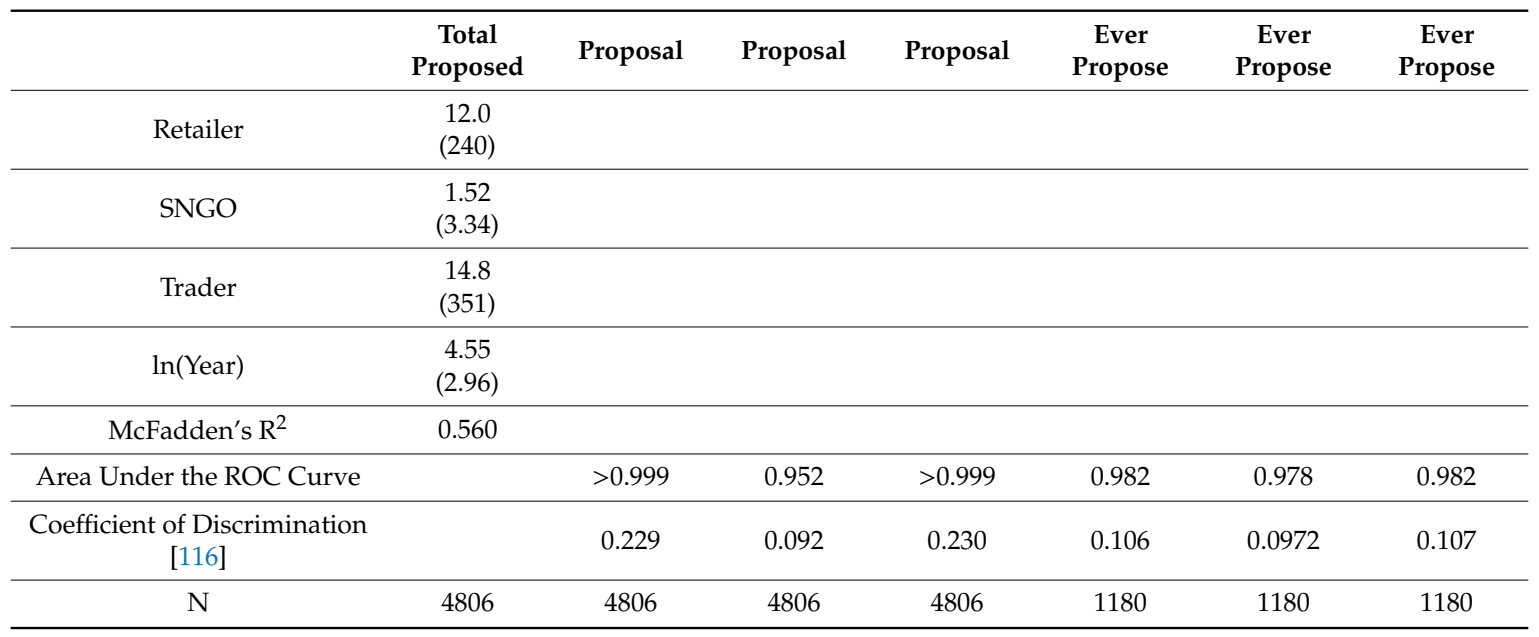

The final three models are aggregated across the observation period and predict whether or not an organization has ever proposed a resolution. ${ }^{*}=$ sig. at $0.05,{ }^{* *}=$ sig. at $0.01,{ }^{* * *}=$ sig. at 0.001 .

Table A2. Estimated models predicting current GB membership.

\begin{tabular}{|c|c|c|c|}
\hline & $\begin{array}{l}\text { Number of GBs } \\
\text { (Poisson) }\end{array}$ & $\begin{array}{c}\text { Number of GBs } \\
\text { (Negative Binomial) }\end{array}$ & On One GB \\
\hline Intercept & $\begin{array}{l}-1.37 \\
(0.877) \\
\end{array}$ & $\begin{array}{l}-1.31 \\
(1.02)\end{array}$ & $\begin{array}{l}-5.51^{* * *} \\
(1.14)\end{array}$ \\
\hline $\ln ($ Years of Membership + 1) & $\begin{array}{l}0.883 * \\
(0.427)\end{array}$ & $\begin{array}{c}0.791 \\
(0.485)\end{array}$ & $\begin{array}{l}1.42 * * * \\
(0.313)\end{array}$ \\
\hline BoG Member & $\begin{array}{c}0.431 \\
(0.336)\end{array}$ & $\begin{array}{c}0.526 \\
(0.467)\end{array}$ & $\begin{array}{l}4.42^{* * *} \\
(1.22)\end{array}$ \\
\hline Founding Member & $\begin{array}{l}-0.420 \\
(2.60)\end{array}$ & $\begin{array}{l}-0.709 \\
(0.851)\end{array}$ & $\begin{array}{l}-1.62 \\
(1.42)\end{array}$ \\
\hline Headquartered in OECD & $\begin{array}{l}-0.622 \\
(0.608)\end{array}$ & $\begin{array}{l}-0.526 \\
(0.560)\end{array}$ & $\begin{array}{c}1.40 * \\
(0.530)\end{array}$ \\
\hline Headquartered in Singapore & $\begin{array}{c}0.555 \\
(0.374)\end{array}$ & $\begin{array}{c}0.563 \\
(0.445)\end{array}$ & $\begin{array}{l}2.64^{* *} \\
(0.703)\end{array}$ \\
\hline ENGO & $\begin{array}{c}1.11 \\
(0.606)\end{array}$ & $\begin{array}{c}0.997 \\
(0.730)\end{array}$ & $\begin{array}{c}0.990 \\
(0.948)\end{array}$ \\
\hline Grower & $\begin{array}{c}0.162 \\
(0.661) \\
\end{array}$ & $\begin{array}{c}0.187 \\
(0.837) \\
\end{array}$ & $\begin{array}{c}0.690 \\
(0.978) \\
\end{array}$ \\
\hline Manufacturer & $\begin{array}{c}1.03 \\
(1.55)\end{array}$ & $\begin{array}{c}1.14 \\
(0.875)\end{array}$ & $\begin{array}{c}-2.9 \\
(0.999)\end{array}$ \\
\hline Retailer & $\begin{array}{l}-2.32 * * \\
(0.805)\end{array}$ & $\begin{array}{l}-2.31^{* *} \\
(0.863)\end{array}$ & $\begin{array}{l}-0.897 \\
(0.999)\end{array}$ \\
\hline SNGO & $\begin{array}{c}0.596 \\
(0.615)\end{array}$ & $\begin{array}{c}0.611 \\
(0.749)\end{array}$ & $\begin{array}{c}3.35 \\
(1.17)\end{array}$ \\
\hline Trader & $\begin{array}{c}0.578 \\
(0.852) \\
\end{array}$ & $\begin{array}{c}0.635 \\
(0.784) \\
\end{array}$ & $\begin{array}{c}-1.64 \\
(0.891) \\
\end{array}$ \\
\hline $\ln (\theta)$ & & $\begin{array}{c}1.93 \\
(1.21)\end{array}$ & \\
\hline
\end{tabular}


Table A2. Cont.

\begin{tabular}{|c|c|c|c|}
\hline & $\begin{array}{l}\text { Number of GBs } \\
\text { (Poisson) }\end{array}$ & $\begin{array}{c}\text { Number of GBs } \\
\text { (Negative Binomial) }\end{array}$ & On One GB \\
\hline Intercept & $\begin{array}{l}5.14 * * \\
(1.64)\end{array}$ & $\begin{array}{l}5.24^{* *} \\
(1.82)\end{array}$ & \\
\hline $\ln ($ Years of Membership + 1) & $\begin{array}{l}-1.31^{* *} \\
(0.459)\end{array}$ & $\begin{array}{l}-1.40 * \\
(0.633)\end{array}$ & \\
\hline BoG Member & $\begin{array}{l}-5.13 * \\
(2.32)\end{array}$ & $\begin{array}{c}-5.31 * * \\
(1.84)\end{array}$ & \\
\hline Founding Member & $\begin{array}{c}1.63 \\
(6.49)\end{array}$ & $\begin{array}{l}0.847 \\
(2.76)\end{array}$ & \\
\hline Headquartered in OECD & $\begin{array}{l}-1.79 * \\
(0.858)\end{array}$ & $\begin{array}{l}-1.78 * \\
(0.792)\end{array}$ & \\
\hline Headquartered in Singapore & $\begin{array}{l}-2.56 * * \\
(0.830)\end{array}$ & $\begin{array}{l}-2.65 * * \\
(0.928)\end{array}$ & \\
\hline ENGO & $\begin{array}{c}-0.679 \\
(1.25)\end{array}$ & $\begin{array}{c}-0.729 \\
(1.32)\end{array}$ & \\
\hline Grower & $\begin{array}{c}-0.846 \\
(1.25)\end{array}$ & $\begin{array}{c}-0.915 \\
(1.40)\end{array}$ & \\
\hline Manufacturer & $\begin{array}{c}3.52 \\
(1.99)\end{array}$ & $\begin{array}{l}3.68^{* *} \\
(1.40)\end{array}$ & \\
\hline Retailer & $\begin{array}{l}-16.3 \\
(824)\end{array}$ & $\begin{array}{l}-13.1 \\
(158)\end{array}$ & \\
\hline SNGO & $\begin{array}{l}-3.42 * \\
(1.52)\end{array}$ & $\begin{array}{l}-3.69 \\
(2.20)\end{array}$ & \\
\hline Trader & $\begin{array}{c}1.89 \\
(1.27)\end{array}$ & $\begin{array}{c}1.96 \\
(1.26)\end{array}$ & \\
\hline McFadden's $\mathrm{R}^{2}$ & 0.370 & 0.360 & \\
\hline Area under the ROC Curve & & & 0.933 \\
\hline $\begin{array}{l}\text { Coefficient of Discrimination } \\
\text { [116] }\end{array}$ & & & 0.08 \\
\hline $\mathrm{N}$ & 1123 & 1123 & 1123 \\
\hline
\end{tabular}

Based on a likelihood ratio test $\left(\chi^{2}=1.39, p=0.239\right)$, we find no statistically significant improvement in model fit from the Poisson to the negative binomial models. ${ }^{*}=$ sig. at $0.05,{ }^{* *}=$ sig. at $0.01,{ }^{* * *}=$ sig. At 0.001 .

\section{References}

1. Dicken, P. Global Shift: Reshaping the Global Economic Map in the 21st Century, 4th ed.; Sage: London, UK, 2003.

2. Gereffi, G.; Humphrey, J.; Sturgeon, T. The Governance of Global Value Chains. Rev. Int. Political Econ. 2005, 12, 78-104. [CrossRef]

3. Rasche, A. Global Policies and Local Practice: Loose and Tight Couplings in Multi-Stakeholder Initiatives. Bus. Ethics Q. 2012, 22, 679-708. [CrossRef]

4. Abbott, K.; Snidal, D. The Governance Triangle: Regulatory Standards Institutions and the Shadow of the State. In The Politics of Global Regulation; Mattli, W., Woods, N., Eds.; Cambridge University Press: Cambridge, UK, 2009; pp. 44-88. [CrossRef]

5. Green, J.F. Rethinking Private Authority: Agents and Entrepreneurs in Global Environmental Governance; Princeton University Press: Princeton, NJ, USA, 2014.

6. Mayer, F.; Gereffi, G. Regulation and Economic Globalization: Prospects and Limits of Private Governance. Bus. Politics 2010, 12, 1-25. [CrossRef]

7. Ponte, S.; Cheyns, E. Voluntary Standards, Expert Knowledge and the Governance of Sustainability Networks. Glob. Netw. 2013, 13, 459-477. [CrossRef] 
8. Ruggie, J.G. Reconstituting the Global Public Domain: Issues, Actors, and Practices. Eur. J. Int. Relat. 2004, 10, 499-531. [CrossRef]

9. Fransen, L.W.; Burgoon, B. Privatizing or Socializing Corporate Responsibility: Business Participation in Voluntary Programs. Bus. Soc. 2014, 53, 583-619. [CrossRef]

10. Cashore, B. Legitimacy and the Privatization of Environmental Governance: How Non-State Market-Driven (NSMD) Governance Systems Gain Rule-Making Authority. Governance 2002, 15, 503-529. [CrossRef]

11. Utting, P. Regulating Business via Multistakeholder Initiatives: A Preliminary Assessment. In Voluntary Approaches to Corporate Responsibility: Readings and a Resource Guide; Jenkins, P.U., Pino, R., Eds.; UN Non-Governmental Liaison Service (NGLS) and United Nations Research Institute for Social Development (UNRISD): Geneva, Switzerland, 2002; pp. 61-130.

12. Banerjee, S. Corporate Social Responsibility: The Good, the Bad, and the Ugly. Crit. Sociol. 2010, 34, 51-79. [CrossRef]

13. Moog, S.; Spicer, A.; Böhm, S. The Politics of Multi-Stakeholder Initiatives: The Crisis of the Forest Stewardship Council. J. Bus. Ethics 2014, 128, 469-493. [CrossRef]

14. Busch, L. Governance in the Age of Global Markets: Challenges, Limits, and Consequences. Agric. Hum. Values 2014, 31, 513-523. [CrossRef]

15. Mena, S.; Palazzo, G. Input and Output Legitimacy of Multi-Stakeholder Initiatives. Bus. Ethics Q. 2012, 22, 527-556. [CrossRef]

16. Schouten, G.; Glasbergen, P. Creating Legitimacy in Global Private Governance: The Case of the Roundtable on Sustainable Palm Oil. Ecol. Econ. 2011, 70, 1891-1899. [CrossRef]

17. Fransen, L.W.; Kolk, A. Global Rule-Setting for Business: A Critical Analysis of Multi-Stakeholder Standards. Organization 2007, 14, 667-684. [CrossRef]

18. Scholte, J.A. Civil Society and Democracy in Cambodia. Glob. Gov. 2002, 8, 281-304. [CrossRef]

19. de Bakker, F.; Rasche, A.; Ponte, S. Multi-Stakeholder Initiatives on Sustainability: A Cross-Disciplinary Review and Research Agenda for Business Ethics. Bus. Ethics Q. 2019, 29, 343-383. [CrossRef]

20. Lawrence, T.B.; Suddaby, R. Institutions and Institutional Work. In Handbook of Organization Studies; Clegg, S., Hardy, C., Lawrence, T.B., Eds.; Sage: London, UK, 2006; pp. 215-254. [CrossRef]

21. Garud, R.; Hardy, C.; Maguire, S. Institutional Entrepreneurship as Embedded Agency: An Introduction to the Special Issue. Organ. Stud. 2007, 28, 957-969. [CrossRef]

22. Lawrence, T.; Suddaby, R.; Leca, B. Institutional Work: Refocusing Institutional Studies of Organization. J. Manag. Inq. 2011, 20, 52-58. [CrossRef]

23. RSPO. About Us. Available online: http://www.rspo.org/about (accessed on 19 October 2019).

24. Oliver, C. The Antecedents of the Institutionalization. Organ. Stud. 1992, 13, 563-588. [CrossRef]

25. Lawrence, T.B.; Winn, M.I.; Jennings, P.D. The Temporal Dynamics of Institutionalization. Acad. Manag. Rev. 2001, 26, 624-644. [CrossRef]

26. Gallemore, C.; Guisinger, A.; Kruuse, M.; Ruysschaert, D.; Jespersen, K. Escaping the “Teenage" Years: The Politics of Rigor and the Evolution of Private Environmental Standards. Ecol. Econ. 2018, 152, $76-87$. [CrossRef]

27. Jespersen, K.; Gallemore, C. The Institutional Work of Payments for Ecosystem Services: Why the Mundane Should Matter. Ecol. Econ. 2018, 146, 507-519. [CrossRef]

28. Hall, R.B.; Biersteker, T.J. The Emergence of Private Authority in the International System. In the Emergence of Private Authority in Global Governance; Cambridge University Press: Cambridge, UK, 2002; Volume 85, pp. 3-22. [CrossRef]

29. Mattli, W.; Büthe, T. Setting International Standards: Technological Rationality or Primacy of Power? World Politics 2003, 56, 1-42. [CrossRef]

30. Ponte, S. "Roundtabling" Sustainability: Lessons from the Biofuel Industry. Geoforum 2014, 54, $261-271$. [CrossRef]

31. Mair, J.; Marti, I.; Ventresca, M.J. Building Inclusive Markets in Rural Bangladesh: How Intermediaries Work Institutional Voids. Acad. Manag. J. 2012, 55, 819-850. [CrossRef]

32. Jarvenpaa, S.L.; Väklikangas, L. From governance void to interactive governing behaviors in new research networks. Acad. Manag. Discov. 2016, 2, 226-246. [CrossRef]

33. O'Rourke, D. Outsourcing Regulation: Analyzing Nongovernmental Systems of Labor Standards and Monitoring. Policy Stud. J. 2003, 31, 1-29. [CrossRef] 
34. Brunsson, N.; Jacobsson, B. The Contemporary Expansion of Standardization. In A World of Standards; Brunsson, N., Jacobsson, B., Eds.; Oxford University Press: Oxford, UK, 2002; pp. 127-137.

35. Djelic, M.-L.; Quack, S. Transnational Governance through Standard Setting. In Capitalisms and Capitalism in the Twenty-First Century; Morgan, G., Whitley, R., Eds.; Oxford University Press: New York, NY, USA, 2012; pp. 1-23.

36. Bäckstrand, K. Multi-Stakeholder Partnerships for Sustainable Development: Rethinking Legitimacy, Accountability and Effectiveness. Eur. Environ. 2006, 16, 290-306. [CrossRef]

37. Suchman, M.C. Managing Legitimacy: Strategic and Institutional Approaches. Acad. Manag. J. 1995, 20, 571-610.

38. Deephouse, D.L.; Bundy, J.; Tost, L.P.; Suchman, M.C. Organizational Legitimacy: Six Key Questions. In The SAGE Handbook of Organizational Institutionalism; Greenwood, C.O., Lawrence, T., Meyer, R., Eds.; Sage Publications, Inc.: Thousand Oaks, CA, USA, 2017; pp. 2-41.

39. Hurd, I. Legitimacy and Authority in International Politics. Int. Organ. 1999, 53, 379-408. [CrossRef]

40. Gulbrandsen, L.H. Accountability Arrangements in Non-State Standards Organizations: Instrumental Design and Imitation. Organization 2008, 15, 563-583. [CrossRef]

41. Young, I.M. Inclusion and Democracy; Oxford University Press: Oxford, UK, 2000.

42. Mahoney, J. Path Dependence in Historical Sociology. Theory Soc. 2000, 29, 507-548. [CrossRef]

43. Pierson, P. Increasing Returns, Path Dependence, and the Study of Politics. Am. Political Sci. Rev. 2000, 94, 251-267. [CrossRef]

44. Black, J. Constructing and Contesting Legitimacy and Accountability in Polycentric Regulatory Regimes. Regul. Gov. 2008, 2, 137-164. [CrossRef]

45. Fransen, L.W. Multi-Stakeholder Governance and Voluntary Programme Interactions: Legitimation Politics in the Institutional Design of Corporate Social Responsibility. Socio-Econ. Rev. 2012, 10, 163-192. [CrossRef]

46. Roberts, J. The Manufacture of Corporate Social Responsibility: Constructing Corporate Sensibility. Organization 2003, 10, 249-265. [CrossRef]

47. Ponte, S. Greener than Thou: The Political Economy of Fish Ecolabeling and Its Local Manifestations in South Africa. World Dev. 2008, 36, 159-175. [CrossRef]

48. Bano, M. Dangerous Correlations: Aid's Impact on NGOs' Performance and Ability to Mobilize Members in Pakistan. World Dev. 2008, 36, 2297-2313. [CrossRef]

49. Cook, L.; Vinogradova, E. NGOs and Social Policy-Making in Russia's Regions. Probl. Post-Communism 2006, 53, 28-41. [CrossRef]

50. Cheyns, E. Multi-Stakeholder Initiatives for Sustainable Agriculture: Limits of the "Inclusiveness" Paradigm. In Governing through Standards: Origins, Drivers and Limitations; Ponte, S., Gibbon, P., Vestergaard, J., Eds.; Palgrave Macmillan: Basingstoke, UK, 2011; pp. 210-235.

51. Baumann-Pauly, D.; Nolan, J.; van Heerden, A.; Samway, M. Industry-Specific Multi-Stakeholder Initiatives That Govern Corporate Human Rights Standards: Legitimacy Assessments of the Fair Labor Association and the Global Network Initiative. J. Bus. Ethics 2017, 143, 771-787. [CrossRef]

52. Carlson, K.M.; Heilmayr, R.; Gibbs, H.K.; Noojipady, P.; Burns, D.N.; Morton, D.C.; Walker, N.F.; Paoli, G.D.; Kremen, C. Effect of Oil Palm Sustainability Certification on Deforestation and Fire in Indonesia. Proc. Natl. Acad. Sci. USA 2018, 115, 121-126. [CrossRef]

53. Cattau, M.E.; Marlier, M.E.; DeFries, R. Effectiveness of Roundtable on Sustainable Palm Oil (RSPO) for Reducing Fires on Oil Palm Concessions in Indonesia from 2012 to 2015. Environ. Res. Lett. 2016, 11. [CrossRef]

54. Gulbrandsen, L.H.; Auld, G. Contested Accountability Logics in Evolving Nonstate Certification for Fisheries Sustainability. Glob. Environ. Politics 2016, 16, 42-60. [CrossRef]

55. Olson, M. The Logic of Collective Action: Public Goods and the Theory of Groups; Harvard University Press: Cambridge, MA, USA, 1965.

56. Moura, P.T.; Chaddad, F.R. Collective Action and the Governance of Multistakeholder Initiatives: A Case Study of Bonsucro. J. Chain Netw. Sci. 2012, 12, 13-24. [CrossRef]

57. Ponte, S. The Marine Stewardship Council (MSC) and the Making of a Market for "Sustainable Fish". J. Agrar. Chang. 2012, 12, 300-315. [CrossRef]

58. Slager, R.; Gond, J.-P.; Moon, J. Standardization as Institutional Work: The Regulatory Power of a Responsible Investment Standard. Organ. Stud. 2012, 33, 763-790. [CrossRef] 
59. Seidl, D. Standard Setting and Following in Corporate Governance: An Observation-Theoretical Study of the Effectiveness of Governance Codes. Organization 2007, 14, 705-727. [CrossRef]

60. DiMaggio, P. Interest and Agency in Institutional Theory. In Institutional Patterns and Organizations: Culture and Environment; Zucker, L.G., Ed.; Ballinger Pub. Co.: Cambridge, UK, 1988; pp. 3-22.

61. Fligstein, N.; McAdam, D. A Theory of Fields; Oxford University Press: New York, NY, USA, 2012.

62. Leblebici, H.; Salancik, G.R.; Copay, A.; King, T. Institutional Change and the Transformation of Interorganizational Fields: An Organizational History of the U.S. Radio Broadcasting Industry. Adm. Sci. Q. 1991, 36, 333-363. [CrossRef]

63. Joutsenvirta, M. A Practice Approach to the Institutionalization of Economic Degrowth. Ecol. Econ. 2016, 128, 23-32. [CrossRef]

64. Lawrence, T.B.; Leca, B.; Zilber, T.B. Institutional Work: Current Research, New Directions and Overlooked Issues. Organ. Stud. 2013, 34, 1023-1033. [CrossRef]

65. Kraatz, M.S. Leadership as Institutional Work: A Bridge to the Other Side. In Institutional Work; Lawrence, T.B., Suddaby, R., Leca, B., Eds.; Cambridge University Press: Cambridge, UK, 2009; pp. 59-91. [CrossRef]

66. Riaz, S.; Buchanan, S.; Bapuji, H. Institutional Work amidst the Financial Crisis: Emerging Positions of Elite Actors. Organization 2011, 18, 187-214. [CrossRef]

67. Rojas, F. Power through institutional work: Acquiring academic authority in the 1968 third world strike. Acad. Manag. J. 2010, 53, 1263-1280. [CrossRef]

68. Suddaby, R.; Viale, T. Professionals and Field-Level Change: Institutional Work and the Professional Project. Curr. Sociol. 2011, 59, 423-442. [CrossRef]

69. Battilana, J.; Leca, B.; Boxenbaum, E. How Actors Change Institutions: Towards a Theory of Institutional Entrepreneurship. Acad. Manag. Ann. 2009, 3, 65-107. [CrossRef]

70. Dang, C.; Li, Z.F.; Yang, C. Measuring Firm Size in Empirical Corporate Finance. J. Bank. Financ. 2018, 86, 159-176. [CrossRef]

71. Elsbach, K.D.; Sutton, R.I. Acquiring Organizational Legitimacy through Illegitimate Actions: A Marriage of Institutional and Impression Management Theories. Acad. Manag. J. 1992, 35, 699-738.

72. Scott, W.R. Institutions and Organizations. Ideas, Interests and Identities.; SAGE Publications, Inc.: Thousand Oaks, CA, USA, 1995. [CrossRef]

73. Russo, M.V. Institutions, Exchange Relations, and the Emergence of New Fields: Regulatory Policies and Independent Power Production in America, 1978-1992. Adm. Sci. Q. 2001, 46, 57-86. [CrossRef]

74. Gebara, M.F.; Agrawal, A. Beyond Rewards and Punishments in the Brazilian Amazon: Practical Implications of the REDD+ Discourse. Forests 2017, 8, 66. [CrossRef]

75. RSPO. Key Documents. Available online: http://www.rspo.org/key-documents (accessed on 19 October 2019).

76. RSPO. Membership. Available online: https://www.rspo.org/members (accessed on 19 October 2019).

77. RSPO. Meetings, Minutes and Reports of the GA \& ExGA. Available online: http://www.rspo.org/keydocuments/supplementary-materials/minutes-reports-of-rspo-ga-ega (accessed on 19 October 2019).

78. RSPO. Meetings, Minutes and Reports of RSPO Board of Governors. Available online: https://www.rspo.org/ key-documents/supplementary-materials/minutes-reports-of-rspo-bog (accessed on 19 October 2019).

79. RSPO. How We Work. Available online: https://www.rspo.org/about/how-we-work (accessed on 19 October 2019).

80. Faroughi, P.; Ismail, N. Bivariate Zero-Inflated Negative Binomial Regression Model with Applications. J. Stat. Comput. Simul. 2017, 87, 457-477. [CrossRef]

81. Long, J.S. Regression Models for Categorical and Limited Dependent Variables; Sage Publications, Inc.: Thousand Oaks, CA, USA, 1997.

82. Hoekman, J.; Frenken, K.; van Oort, F. The Geography of Collaborative Knowledge Production in Europe. Ann. Reg. Sci. 2009, 43, 721-738. [CrossRef]

83. Erdman, D.; Jackson, L.; Sinko, A. Zero-Inflated Poisson and Zero-Inflated Negative Binomial Models Using the COUNTREG Procedure; SAS Institute: Cary, NC, USA, 2008.

84. Firth, D. Bias Reduction of Maximum Likelihood Estimates. Biometrika 1993, 1, 27-38. [CrossRef]

85. Heinze, G.; Ploner, M.; Dunkler, D.; Southworth, H. logistf: Firth's Bias-Reduced Logistic Regression. Available online: https://cran.r-project.org/web/packages/logistf/index.html (accessed on 19 October 2019). 
86. R Core Team. R: A Language and Environment for Statistical Computing; R Foundation for Statistical Computing: Vienna, Austria; Available online: https://www.R-project.org/ (accessed on 19 October 2019).

87. Stanford FSI. New Grant for Palm Oil Research. Available online: http://fsi.stanford.edu/news/new-grantoil-palm-research (accessed on 19 October 2019).

88. Kongsager, R.; Reenberg, A. Contemporary Land-Use Transitions: The Global Oil Palm Expansion; No. GLP Report No. 4; GLP International Project Office: Copenhagen, Denmark, 2012; pp. 1-39.

89. Feintrenie, L. Agro-Industrial Plantations in Central Africa, Risks and Opportunities. Biodivers. Conserv. 2014, 23, 1577-1589. [CrossRef]

90. Gutiérrez-Vélez, V.H.; DeFries, R. Annual Multi-Resolution Detection of Land Cover Conversion to Oil Palm in the Peruvian Amazon. Remote Sens. Environ. 2013, 129, 154-167. [CrossRef]

91. Pacheco, P. Soybean and Oil Palm Expansion in South America. A Review of Main Trends and Implications; Center for International Forestry Research: Bogor, Indonesia, 2012.

92. Villela, A.A.; Jaccoud, D.B.; Rosa, L.P.; Freitas, M.V. Status and Prospects of Oil Palm in the Brazilian Amazon. Biomass Bioenergy 2014, 67, 270-278. [CrossRef]

93. Pirker, J.; Mosnier, A.; Kraxner, F.; Havlík, P.; Obersteiner, M. What Are the Limits to Oil Palm Expansion? Glob. Environ. Chang. 2016, 40, 73-81. [CrossRef]

94. Gatto, M.; Wollni, M.; Asnawi, R.; Qaim, M. Oil Palm Boom, Contract Farming, and Rural Economic Development: Village-Level Evidence from Indonesia. World Dev. 2017, 95, 127-140. [CrossRef]

95. Euler, M.; Krishna, V.; Schwarze, S.; Siregar, H.; Qaim, M. Oil Palm Adoption, Household Welfare, and Nutrition among Smallholder Farmers in Indonesia. World Dev. 2017, 93, 219-235. [CrossRef]

96. FAOSTAT. Food and Agriculture Data. Available online: http://www.fao.org/faostat/ (accessed on 19 October 2019).

97. Wickham, H. Ggplot2: Elegant Graphics for Data Analysis; Springer: New York, NY, USA, 2009.

98. Carlson, K.M.; Curran, L.M.; Asner, G.P.; Pittman, A.M.; Trigg, S.N.; Marion Adeney, J. Carbon Emissions from Forest Conversion by Kalimantan Oil Palm Plantations. Nat. Clim. Chang. 2013, 3, 283-287. [CrossRef]

99. Harris, N.L.; Brown, S.; Hagen, S.C.; Saatchi, S.S.; Petrova, S.; Salas, W.; Hansen, M.C.; Potapov, P.V.; Lotsch, A. Baseline Map of Carbon Emissions from Deforestation in Tropical Regions. Science 2012, 336, 1573-1576. [CrossRef]

100. Vijay, V.; Pimm, S.L.; Jenkins, C.N.; Smith, S.J. The Impacts of Oil Palm on Recent Deforestation and Biodiversity Loss. PLoS ONE 2016, 11, e0159668. [CrossRef]

101. Amnesty International. The Great Palm Oil Scandal: Labour Abuses behind Big Brand Names; Amnesty International: London, UK, 2016.

102. Gerber, J.-F. Conflicts over Industrial Tree Plantations in the South: Who, How and Why? Glob. Environ. Chang. 2011, 21, 165-176. [CrossRef]

103. Li, T.M. Social Impacts of Oil Palm in Indonesia: A Gendered Perspective from West Kalimantan; Center for International Forestry Research (CIFOR): Bogor, Indonesia, 2015. [CrossRef]

104. Li, T.M. The Price of Un/Freedom: Indonesia's Colonial and Contemporary Plantation Labor Regimes. Comp. Stud. Soc. Hist. 2017, 59, 245-276. [CrossRef]

105. Li, T.M. Intergenerational Displacement in Indonesia's Oil Palm Plantation Zone. J. Peasant Stud. 2017, 44, 1158-1176. [CrossRef]

106. Obidzinski, K.; Adriani, R.; Komarudin, H.; Andrianto, A. Environmental and Social Impacts of Oil Palm Plantations and Their Implications for Biofuel Production in Indonesia. Ecol. Soc. 2012, 17, 25. [CrossRef]

107. Rival, A.; Levang, P. Palms of Controversies Oil Palm and Development Challenges; Center for International Forestry Research (CIFOR): Bogor, Indonesia, 2014.

108. RSPO. Minutes of the Preparatory Meeting. Available online: http://www.rdeman.nl/site/download/minutess.pdf (accessed on 19 October 2019).

109. RSPO. Meeting on the Round Table for Sustainable Palm Oil. Available online: http://www.rspo.org/sites/ default/files/Minutes_2002-12-17.pdf (accessed on 19 October 2019).

110. SPOTT. World Wildlife Fund (WWF). Available online: https://www.spott.org/palm-oil-resource-archive/ case-studies/world-wildlife-fund-wwf/ (accessed on 19 October 2019).

111. RSPO. Roundtable for Sustainable Palm Oil II. Available online: http://www.rspo.org/files/pdf/RT2/ Proceedings/Day1/RT2Opening(JK).pdf (accessed on 19 October 2019). 
112. RSPO. RSPO Membership Rules 2016. Available online: https://www.rspo.org/library/lib_files/preview/58 (accessed on 19 October 2019).

113. RSPO. RSPO Standard Operating Procedure for Standards Setting and Review. Available online: https: //www.rspo.org/key-documents/certification/standards-setting-process (accessed on 19 October 2019).

114. RSPO. The Statutes of The Roundtable on Sustainable Palm Oil. Available online: http://www.rspo.org/keydocuments/membership (accessed on 19 October 2019).

115. Partzsch, L. The Legitimacy of Biofuel Certification. Agric. Hum. Values 2011, 28, 413-425. [CrossRef]

116. Tjur, T. Coefficients of Determination in Logistic Regression Models-A New Proposal: The Coefficient of Discrimination. Am. Stat. 2009, 63, 366-372. [CrossRef]

117. Fruchterman, T.M.J.; Reingold, E.M. Graph Drawing by Force-Directed Placement. Softw. Pract. Exp. 1991, 21, 1129-1164. [CrossRef]

118. Weik, E. Institutional Entrepreneurship and Agency. J. Theory Soc. Behav. 2011, 41, 466-481. [CrossRef]

119. Micelotta, E.; Lounsbury, M.; Greenwood, R. Pathways of Institutional Change: An Integrative Review and Research Agenda. J. Manag. 2017, 43, 1885-1910. [CrossRef]

120. Dacin, M.T.; Goodstein, J.; Scott, W.R. Institutional Theory and Institutional Change: Introduction to the Special Research Forum. Acad. Manag. J. 2002, 45, 45-56. [CrossRef]

121. Creswell, J.W. Research Design: Qualitative, Quantitative, and Mixed Methods Approaches, 4th ed.; SAGE Publications, Inc.: Thousand Oaks, CA, USA, 2014.

(C) 2019 by the authors. Licensee MDPI, Basel, Switzerland. This article is an open access article distributed under the terms and conditions of the Creative Commons Attribution (CC BY) license (http://creativecommons.org/licenses/by/4.0/). 